\title{
The long run impact of childhood interracial contact on residential segregation
}

\author{
LUCA PAOLO MERLINO \\ ECARES, Université libre de Bruxelles \\ MAX FRIEDRICH STEINHARDT \\ Free University of Berlin, IZA and LdA \\ LIAM WREN-LEWIS \\ Paris School of Economics and INRAE
}

January 23, 2023

\begin{abstract}
This paper exploits quasi-random variation in the share of Black students across cohorts within US schools to investigate whether childhood interracial contact impacts the residential choices of Whites when they are adults. We find that, 20 years after exposure, Whites who had more Black peers of the same gender in their grade go on to live in census tracts with more Black residents. Further investigation suggests that this result is unlikely to be driven by economic opportunities or social networks. Instead, the effect on residential choice appears to come from a change in preferences among Whites.
\end{abstract}

Acknowledgments: We would like to thank participants at EALE 2022, EMUEA 2022, ESPE 2022, Verein fuer Socialpolitik 2022 and seminars at PSE and Utrecht for helpful comments and suggestions. This project has benefited from support by Research Foundation Flanders-FWO (G029621N) and the French National Research Agency (ANR-20-CE41-0014-01 \& ANR-17-EURE-0001). We thank Bradford Morbeck for excellent research assistance. The usual disclaimers apply. 


\section{Introduction}

Racial segregation is a salient and durable characteristic of life in American cities. Even fifty years after the civil rights era, Black-White segregation remains at very high levels. According to the 2020 census, the average White metropolitan area resident lives in a neighborhood that is 9\% Black, while the average Black resident lives in a neighborhood that is $41 \%$ Black (Logan and Stults, 2022). The social and economic consequences range from adverse effects on education and earnings to negative effects on health behavior and outcomes (Ananat, 2011; Logan and Parman, 2017; Niemesh and Shester, 2020; Derenoncourt, 2022). The latter has been tragically highlighted by the COVID-19 pandemic, during which segregated counties in the US experienced above-average death and infection rates (TorratsEspinosa, 2021).

The literature differentiates between three different causes of racial residential segregation: actions to exclude Black people from predominantly White neighborhoods, preference-based self-selection of Black people into Black neighborhoods, and White people choosing not to live in neighborhoods with higher shares of Black residents (e.g., Cutler et al., 1999; Boustan, 2017; Aliprantis et al., 2022). The empirical evidence suggests that the latter is one of the most important factors in explaining the persistence of Black-White segregation in the US (Crowder, 2000; Boustan, 2010; Shertzer and Walsh, 2019). Card et al. (2008) document a substantial heterogeneity in segregation dynamics over time and across regions, and find this to be correlated with Whites' racial attitudes. Yet little is known about the mechanisms behind this relationship, or the extent to which preferences can be changed to reduce residential segregation.

This paper addresses this research gap and investigates whether exposure of Whites to Black peers at a young age can reduce residential racial segregation. In particular, we analyze how plausibly exogenous variation in a White student's school cohort affects residential location choices later in life. The data used comes from the National Longitudinal Survey of Adolescent Health (Add Health) which, for a nationally representative sample of adolescents, provides information on the race of all students in their school and then surveys them at various points over 
the next twenty years. This allows us to exploit idiosyncratic variation in grade composition within schools, a methodology first proposed by Hoxby (2000) that has since been widely used to identify causal peer effects. ${ }^{1}$ We provide several tests giving evidence that the variation we use is good as random and uncorrelated with other variables that might influence residential choices.

The main contribution of this paper is then to demonstrate that the racial composition of students' school cohorts impacts residential location choices later in life. We find that White individuals who were in grades with more Black students of the same gender in 1994-95 are more likely to live in neighborhoods with more Black residents in 2016-18. The magnitude of the effect implies that going from the average of 8 percent Black students of the same gender in the grade to 10 percent increases the share of Black residents in one's neighborhood two decades later by almost 0.4 percentage points, which is 5 percent of the mean. The results are robust to several modifications of the model, including the introduction of grade-school and census tract fixed effects.

A priori, these results could be driven by three distinct channels: economic opportunities, social networks, and racial preferences. We provide several pieces of evidence which speak against economic opportunities being a major force behind our results. We find no effect of cohort racial composition on individual education and labor market outcomes, nor do we detect any impact on other neighborhood characteristics such as average income or property value. We further document that our results are unlikely to be driven directly by friendships and social ties formed in school nor by the preferences of partners in interracial relationships. Instead, it appears our results are likely to be shaped by changes in racial attitudes. Consistent with this, we find positive effects of exposure to Black peers on White adults' stated liberalness and the likelihood of interracial partnership, and find that exposure to Blacks in school changes the relationship between neighborhood racial composition, neighborhood satisfaction, and moving decisions. In particular, our estimates suggest that, for those exposed to a greater share of Black peers in schools, there

\footnotetext{
${ }^{1}$ See, for example, Bifulco et al. (2011); Lavy et al. (2012); Patacchini and Zenou (2016); Carrell et al. (2018); Fruehwirth et al. (2019); Merlino et al. (2019). We also exploit idiosyncratic variation in gender shares across grades within a school in a similar manner to papers such as Lavy and Schlosser (2011) and Hill (2015).
} 
is a reduction in patterns associated with 'White flight' (Schelling, 1971; Boustan, 2010; Bayer et al., 2022). This is consistent with interracial contact changing Whites' attitudes towards mixing with Blacks (Williams, 1947; Allport, 1954).

Our paper therefore contributes to the literature on residential segregation (Massey and Denton, 1993; Charles, 2003; Boustan, 2011). In particular, we highlight how social contact with Blacks in high school can in the long run help to reduce the propensity of Whites to avoid living in Black neighbourhoods. In doing so, we complement a body of related work examining how White parents react to changes in the overall racial composition of schools (e.g., Baum-Snow and Lutz, 2011). In particular, our study differs by analyzing the impact of quasi-random within-school variation, which is unobservable by parents when choosing a school or residential location.

We also contribute to the literature on how interracial contact shapes attitudes and behavior. Increasing evidence finds that contact between groups can change attitudes and influence behavior (e.g., Bazzi et al., 2019; Carrell et al., 2019; Mousa, 2020; Boucher et al., 2021; Bursztyn et al., 2021; Lowe, 2021; Corno et al., 2022). Yet there is still little evidence on whether such contact can have important behavioral impacts a long time after the contact has occurred. Exceptions to this have analyzed outcomes in two other domains: interracial relationships (Gordon and Reber, 2018; Merlino et al., 2019) and political behavior (Billings et al., 2021; Polipciuc et al., 2021; Schindler and Westcott, 2021). We add to this literature by analysing a related and so far unexplored dimension: the long-run effect of interracial exposure on residential location choices.

The remainder of the paper is organized as follows. Section 2 describes the data set and estimation strategy, and provides evidence in favor of our main identification assumption. In Section 3, we present our benchmark results and several robustness checks. Section 4 interprets our empirical findings and discusses potential channels at play. Finally, Section 5 concludes and briefly discusses policy implications. 


\section{Data and Estimation Strategy}

\subsection{Data}

We use data from the National Longitudinal Survey of Adolescent Health (Add Health). ${ }^{2}$ The survey selected 80 nationally representative high schools and 54 feeder schools in the US and first gave a questionnaire to all students in the schools in grades 7-12 in 1994-95. This in-school survey was self-administered and collected basic information from around 90,000 students, including their gender and race. Within each school a sample of students was then interviewed at home and asked many detailed questions on topics including family background, health behaviors and friendships. This in-home survey was administered to around 20,000 students (of whom around 13,000 are White), who then constituted the base sample for the subsequent waves, administered in 1996 (Wave 2), 2001-02 (Wave 3), 2008-09 (Wave 4), and 2016-18 (Wave 5).

In a first step, we derive information about school peers using all respondents of the in-school survey. As this is basically a census of students, using this data minimizes measurement error in constructing our main independent variables, i.e., the shares of students in peer groups who are Black. ${ }^{3}$ We consider three alternative groups of peers, which we refer to as cohorts: all those in the same grade, those of the same sex in the same grade, and those of opposite sex in the same grade.

In contrast to Merlino et al. (2019) and Polipciuc et al. (2021), our analysis then uses the data from Wave 5 to retrieve our main dependent variable, that is, the share of Blacks in the census tract of the respondent's residence in 2016-18. ${ }^{4}$ This

\footnotetext{
${ }^{2}$ The Add Health project was designed by J. Richard Udry, Peter S. Bearman, and Kathleen Mullan Harris, and funded by a grant P01-HD31921 from the National Institute of Child Health and Human Development, with cooperative funding from 23 other federal agencies and foundations. Special acknowledgment is due Ronald R. Rindfuss and Barbara Entwisle for assistance in the original design. Persons interested in obtaining data files from Add Health should contact Add Health, Carolina Population Center, 123 W. Franklin Street, Chapel Hill, NC 27516-2524 (Add Health@unc.edu). No direct support was received from grant P01-HD31921 for this analysis.

${ }^{3}$ In the in-school survey, students self-report the race they identify with, with a small percentage citing more than one race. In this paper, the Black share is defined as the share of students who identify themselves as Black only.

${ }^{4}$ Census tracts are small geographic areas: they generally have between 1,500 and 8,000 people, with an optimum size of 4,000 people each. They are commonly used to present information for
} 
is estimated by Add Health using the American Community Survey and linked to all geolocated individuals interviewed in Wave 5. We also make use of other information provided by the Wave 5 survey including the respondent's education, labor market outcomes, and other tract characteristics.

We focus our attention on White students since they constitute the majority group, which is of primary interest when considering racial attitudes toward minorities. The relatively small number of students of other racial groups limits our ability to draw robust inference on whether they are affected differently. Of the 8,061 Whites interviewed in Wave 5 we have location data for 7,520 respondents, of whom we were unable to match 420 with information on their school cohort. ${ }^{5}$ This leaves us with a total of 7,090 individuals, spread across 126 schools, 434 school cohorts, and 840 peer groups of the same grade and same gender.

In terms of attrition, Bifulco et al. (2011) and Merlino et al. (2019) find no evidence that attrition in Wave 4 is correlated with minority shares within cohorts. In our sample, there is no systematic relationship between one's cohort Black shares and the probability to be in our Wave 5 sample or the probability of not responding to the first request to participate in Wave 5. Additionally, our results are robust to using sample weights and are improved by including individuals who didn't respond at the first request to participate in Wave 5. See Appendix Table A9 for more details.

Summary statistics of the main variables we use in our analysis are reported in Table 1. For individuals in our sample, the mean share of Blacks in the census tract in Wave 5 (our main outcome variable) is around 8\%. Interestingly, the standard deviation is higher within schools than between them, suggesting that it is reasonable to look for factors which determine this outcome using within-school variation.

In contrast, it should be noted that the variation in grade Black share within schools is relatively low, being about 1.5 percentage points for the both gender measure and 2.5 percentage points for the same gender measure. ${ }^{6}$ In this sense,

small towns, rural areas, and neighborhoods, and hence they provide us with a measure of local segregation. To give an idea, in the US there are about 74,000 census tracts.

${ }^{5}$ Moreover, we drop 10 White students who we were not able to match to the in-school data in more than one cohort.

${ }^{6}$ Note that one reason these standard deviations are low is that a number of schools in our sample 
Table 1: Summary statistics

\begin{tabular}{lcccc}
\hline & Mean & $\begin{array}{c}\text { Within } \\
\text { school } \\
\text { s.d. }\end{array}$ & $\begin{array}{c}\text { Between } \\
\text { school } \\
\text { s.d. }\end{array}$ & N \\
\hline Main variables & & & & \\
Share of census tract Black, Wave 5 & .0818566 & .1067597 & .0792128 & 7090 \\
Share of census tract Black, Wave 1 & .054636 & .0634313 & .117575 & 7034 \\
Grade Black share, both genders & .0797002 & .0155908 & .192231 & 7090 \\
Grade Black share, same gender & .0792521 & .0252516 & .189996 & 7090 \\
Other Wave 1 variables & & & & \\
Age & 16.00944 & 1.068762 & 1.372499 & 7090 \\
Female & .5557752 & .4689177 & .1358581 & 7090 \\
Hispanic & .1251059 & .1937875 & .2293006 & 7090 \\
Family income ( 000's) & 52.32824 & 33.6119 & 24.79959 & 5705 \\
Grade size & 223.7108 & 23.55905 & 132.1165 & 7090 \\
School size & 820.3257 & 0 & 514.74 & 7090 \\
Grades in school & 4.094041 & 0 & 1.211375 & 7090 \\
In middle school & .2190059 & 0 & .4911923 & 7090 \\
In high school & .5866987 & 0 & .4968472 & 7090 \\
Lives in urban area & .4562153 & .1659608 & .4297206 & 7031 \\
Region = Northeast & .1832816 & 0 & .4119639 & 7090 \\
Region = Midwest & .3076814 & 0 & .427618 & 7090 \\
Region = South & .3407229 & 0 & .4875595 & 7090 \\
Region = West & .168314 & 0 & .3592762 & 7090 \\
\hline
\end{tabular}

our data has two advantages. First, given that the within-school standard deviation is between 20-30\% of the mean, the variation in grade Black share within schools is substantial enough to generate important variations in exposure. Second, while we are unable to look at impacts of very large changes in grade Black shares in percentage point terms, the focus on small variations has the advantage that they are unlikely to trigger drastic behavioral responses by parents, such as changes in residence or schools to avoid contact with minorities.

\subsection{Estimation Strategy}

Directly regressing residential segregation on cohort composition may produce biased results since cohort composition is likely to be correlated with several (possibly omitted) variables that impact residential choice-not least, the composition of the population that lives nearby the school. Moreover, self-selection of individuals into

have no Blacks in any grade, and hence a standard deviation of zero. We keep individuals in these schools in our analysis, but since these schools do not contribute directly to our main results are extremely similar when we remove them. 
schools is problematic, as parents who are more inclined to live in Blacker neighborhoods may choose to enroll their kids in schools with a larger share of Black students.

In order to control for these factors, we exploit variation in the share of Black students across cohorts within an individual school. In other words, we assume that parents select a school for their kids independently of the differences between the average school composition and their child's school specific cohort (which is not observed at the time of enrollment). To implement our identification strategy, we estimate the following regression equation:

$$
Y_{i}=\alpha \text { ShareBlack }_{c s}+I_{g m}+I_{s m}+\varepsilon_{i},
$$

where ShareBlack ss $_{\text {is }}$ the share of Blacks within cohort $c$ in school $s, I_{g m}$ are gradegender fixed effects, $I_{s m}$ are school-gender fixed effects, and $\varepsilon_{i}$ is a random error term. As we show below, the gendered racial composition of grades plays a significant role in our analysis. Hence, we split school and grade fixed effects by gender. Controlling for grade essentially also controls for respondents' age at the time of the Wave 5 interview. Standard errors are clustered at the school level. ${ }^{7}$ Our main dependent variable $Y_{i}$ is the share of the population that are Black living in the same census tract as the respondent in Wave 5.

In our regressions, we first define a cohort as those students who are in the same grade within the school in Wave 1. We subsequently split each grade in two groups, considering separately those students of the opposite gender and those of the same gender. The idea is that peers of the same gender may influence individuals' behavior more if this is the group with which they are most likely to interact, which we will test for by regressing measures of interaction as dependent variables.

\footnotetext{
${ }^{7}$ We cluster standard errors at the school level since students are sampled using a two-stage process in which first a sample of schools are selected-see Abadie et al. (2022) for a discussion. Results are robust to clustering at the school-grade level or the school-gender level.
} 


\subsection{Identification Assumption}

Our methodology relies on the assumption that variation in cohort composition within schools is as good as random once we control for grade-gender fixed effects. The idea is that while families might choose which school to send their kids to based on the average racial composition of the school, the differences between the average school composition and their child's school specific cohort do not play a role. We test three implications of this identification assumption.

First, we perform several balancing tests. In other words, we test whether within-school variation in the share of Black students is correlated with predetermined individual level variables. In particular, we regress a range of predetermined student characteristics on the Black share of their peer group controlling for schoolgender and grade-gender fixed effects. For each characteristic, we perform two different balancing tests: first, regressing it on the Black share of students in each grade, and then simultaneously regressing on the Black share of students of opposite and same sex in each grade. We show in Table 2 the results of some of these balancing tests on the main sample we use in our analysis-results are very similar when we use samples relevant to supplementary regressions. The results support our main identification assumption. In particular, only two of the predetermined variables in table, grade size and language spoken at home being different from English, are significantly different from zero at the 0.10 level, and only in some of the tests. We believe the correlation with these variables to be spurious; however, we control for them in all of our regressions. ${ }^{8}$

One concern may be that we lack power to detect small correlations between our main treatment variables and observables which influence future residential location choice. In addition to undertaking balance tests on the variables individually, we also combine all of our predetermined variables to predict the Wave 5 tract Black share of each individual. We then test for whether this predicted value is correlated

\footnotetext{
${ }^{8}$ Summary statistics of these variables are presented in Table B11. Additionally, we run regressions like those reported in Table 2 for a comprehensive set of pre-treatment student characteristics available in Add Health and observe how many coefficients are significant at the 5 percent level. Of the 86 variables, $9 \%$ are significant when regressed on the both gender Black share, $6 \%$ when regressed on the same gender Black share, and $6 \%$ when regressed on the opposite gender Black share, consistent with the Black shares being distributed quasi-randomly.
} 
with any of our treatment variables in the final row of Table 2 and find no significant correlation.

Second, we test for non-random clustering of Black students across grades within schools: if variation is as good as random, then the race of a student should be uncorrelated with that of their peers once we control for school-gender fixed effects. However, we need to take into account that each individual is present in many others' peer groups but not their own (Guryan et al., 2009). We therefore perform several tests designed to address this issue, including those proposed by Guryan et al. (2009) and Caeyers and Fafchamps (2016). More details can be found in Appendix C. Overall, none of the tests rejects random clustering. We also find no evidence that children who switch out of schools with high Black shares are less likely to live in Black neighborhoods later on. We therefore conclude that the distribution of Blacks after controlling for fixed effects is consistent with quasi-random variation.

Third, we investigate whether differences in Black shares across grades are symmetric. If changes in grade Black share were driven by Blacks dropping out disproportionately, then we might observe that Black shares were systematically lower in later grades. In Appendix C, we plot the distribution of differences in the Black shares between grades. We find the distribution to be very symmetric, which is consistent with differences across grade being as good as random.

An additional concern is that the variation in the share of Black students across grades could be potentially affected by the end of court-ordered desegregation orders in the early nineties. Indeed, the expiration of court oversight led to significant changes in racial composition of school districts (Lutz, 2011). However, during the time in which we study exposure in schools (Wave 1, 1994/1995) most of the court-ordered desegregation plans were still in place. Based on a representative survey of schools collected by Rossell and Armor (1996), only 6 out of 130 school districts that had court-ordered desegregation plans dismissed these before 1996 (Lutz, 2011). Therefore, it is very unlikely that the variation we use stems from the dismissal of desegregation plans. In line with this, Table 2 shows that there is no significant correlation between variation in cohort composition and Wave 1 neighborhood Black shares. This strongly suggests that changes in the indepen- 
Table 2: Balancing tests for cohort composition measures

\begin{tabular}{|c|c|c|c|c|}
\hline & (1) & (2) & (3) & (4) \\
\hline & & \multicolumn{3}{|c|}{ Independent variable: } \\
\hline & $\mathrm{N}$ & $\begin{array}{c}\text { Grade } \\
\text { Black } \\
\text { share, } \\
\text { both } \\
\text { genders }\end{array}$ & $\begin{array}{l}\text { Grade } \\
\text { Black } \\
\text { share, } \\
\text { opp. } \\
\text { gender }\end{array}$ & $\begin{array}{l}\text { Grade } \\
\text { Black } \\
\text { share, } \\
\text { same } \\
\text { gender }\end{array}$ \\
\hline Age & 7,090 & $\begin{array}{l}0.0191 \\
(0.440)\end{array}$ & $\begin{array}{l}-0.113 \\
(0.264)\end{array}$ & $\begin{array}{c}-0.0846 \\
(0.297)\end{array}$ \\
\hline Parent is Black & 6,350 & $\begin{array}{c}0.0441 \\
(0.0269)\end{array}$ & $\begin{array}{l}0.00399 \\
(0.0355)\end{array}$ & $\begin{array}{c}0.0543 \\
(0.0486)\end{array}$ \\
\hline Share of census tract black & 7,034 & $\begin{array}{c}0.0102 \\
(0.0851)\end{array}$ & $\begin{array}{c}0.0329 \\
(0.0613)\end{array}$ & $\begin{array}{r}-0.00589 \\
(0.0588)\end{array}$ \\
\hline Share of census block black & 7,030 & $\begin{array}{l}0.00335 \\
(0.0976)\end{array}$ & $\begin{array}{c}0.0374 \\
(0.0635)\end{array}$ & $\begin{array}{c}-0.0164 \\
(0.0816)\end{array}$ \\
\hline Grade size & 7,090 & $\begin{array}{l}125.8^{*} \\
(74.95)\end{array}$ & $\begin{array}{l}72.61^{*} \\
(39.33)\end{array}$ & $\begin{array}{c}59.76 \\
(43.77)\end{array}$ \\
\hline Share same gender & 7,090 & $\begin{array}{c}0.0215 \\
(0.0701)\end{array}$ & $\begin{array}{c}0.0180 \\
(0.0428)\end{array}$ & $\begin{array}{l}-0.0693 \\
(0.0478)\end{array}$ \\
\hline Born in USA & 7,090 & $\begin{array}{l}0.00679 \\
(0.0836)\end{array}$ & $\begin{array}{c}0.0643 \\
(0.0514)\end{array}$ & $\begin{array}{l}-0.0303 \\
(0.0628)\end{array}$ \\
\hline Lives with both biological parents & 6,326 & $\begin{array}{l}0.0871 \\
(0.359)\end{array}$ & $\begin{array}{c}0.165 \\
(0.216)\end{array}$ & $\begin{array}{r}-0.0447 \\
(0.245)\end{array}$ \\
\hline Number of older siblings & 7,081 & $\begin{array}{l}-0.481 \\
(0.748)\end{array}$ & $\begin{array}{l}0.0745 \\
(0.498)\end{array}$ & $\begin{array}{l}-0.492 \\
(0.435)\end{array}$ \\
\hline Years of parental schooling & 6,816 & $\begin{array}{c}1.254 \\
(1.191)\end{array}$ & $\begin{array}{c}1.233 \\
(0.746)\end{array}$ & $\begin{array}{l}0.0601 \\
(0.823)\end{array}$ \\
\hline Log of family income & 5,650 & $\begin{array}{c}0.611 \\
(0.524)\end{array}$ & $\begin{array}{c}0.422 \\
(0.334)\end{array}$ & $\begin{array}{l}0.0594 \\
(0.356)\end{array}$ \\
\hline Home language is not English & 7,090 & $\begin{array}{c}0.143 \\
(0.0970)\end{array}$ & $\begin{array}{c}0.0201 \\
(0.0641)\end{array}$ & $\begin{array}{c}0.145^{*} \\
(0.0760)\end{array}$ \\
\hline Predicted Wave 5 tract Black share & 7,090 & $\begin{array}{l}-0.0148 \\
(0.0142)\end{array}$ & $\begin{array}{l}-0.0141 \\
(0.0112)\end{array}$ & $\begin{array}{c}0.00458 \\
(0.0147)\end{array}$ \\
\hline
\end{tabular}

Notes: The table reports OLS estimates controlling for grade size, language spoken at home in Wave 1, grade-gender fixed effects, and school-gender fixed effects. Coefficients in each row are from two separate regressions: the first where the variable in the first column is regressed on the overall grade Black share, and the second and third where the variable is regressed on the same gender and opposite gender Black shares simultaneously. Standard errors (in brackets) are clustered at the school level. $* p<.10, * * p<.05, * * * p<.01$ 
dent variables of interest are not systematically driven by changes in the residential location of pupils, nor by changes in its racial composition.

Given these results, we conclude that the variation in Black students across grades within schools is as good as random.

\section{Main Results}

Before analyzing the impact of grade racial composition on residential choices, we look at whether a more diverse student population in school translates into close social contact. Indeed, our empirical strategy relies on the implicit assumption that a higher share of Blacks in a school cohort implies that White students are exposed more to Black students. Students however could react to differences in composition by avoiding people with different background, leading to de facto segregation in schools. This would occur, for example, if they form very segregated friendship networks (Currarini et al., 2009; Mele, 2017). It is therefore important to test this assumption, and we can do so using information on contact provided in the Add Health data.

Table 3: Impacts of grade shares on childhood exposure and friendship

\begin{tabular}{|c|c|c|c|c|c|c|c|c|}
\hline \multirow[t]{3}{*}{ Dependent variable: } & \multicolumn{4}{|c|}{ Share of classmates Black } & \multicolumn{4}{|c|}{ Has at least one Black among set of } \\
\hline & \multicolumn{2}{|c|}{ in Wave 1} & \multicolumn{2}{|c|}{ in Wave 2} & \multicolumn{2}{|c|}{ closest classmates } & \multicolumn{2}{|c|}{ friends } \\
\hline & (1) & (2) & (3) & (4) & (5) & (6) & (7) & (8) \\
\hline $\begin{array}{l}\text { Grade Black share, } \\
\text { both genders }\end{array}$ & $\begin{array}{l}0.407^{* * *} \\
(0.0385)\end{array}$ & & $\begin{array}{l}0.296^{* * *} \\
(0.0493)\end{array}$ & & $\begin{array}{l}0.419^{* * *} \\
(0.114)\end{array}$ & & $\begin{array}{l}0.167^{* *} \\
(0.0761)\end{array}$ & \\
\hline $\begin{array}{l}\text { Grade Black share, } \\
\text { same gender }\end{array}$ & & $\begin{array}{l}0.200^{* * *} \\
(0.0274)\end{array}$ & & $\begin{array}{l}0.288^{* * *} \\
(0.0364)\end{array}$ & & $\begin{array}{l}0.467^{* * *} \\
(0.0809)\end{array}$ & & $\begin{array}{l}0.206^{* * *} \\
(0.0550)\end{array}$ \\
\hline $\begin{array}{l}\text { Grade Black share, } \\
\text { opposite gender }\end{array}$ & & $\begin{array}{l}0.191^{* * *} \\
(0.0244)\end{array}$ & & $\begin{array}{c}0.0276 \\
(0.0299)\end{array}$ & & $\begin{array}{l}-0.0561 \\
(0.0722)\end{array}$ & & $\begin{array}{l}-0.0186 \\
(0.0529)\end{array}$ \\
\hline Observations & 2623 & 2623 & 2044 & 2044 & 2623 & 2623 & 7090 & 7090 \\
\hline Adjusted $R^{2}$ & 0.924 & 0.924 & 0.916 & 0.917 & 0.137 & 0.144 & 0.019 & 0.020 \\
\hline Dep. var. mean & 0.085 & 0.085 & 0.084 & 0.084 & 0.012 & 0.012 & 0.015 & 0.015 \\
\hline
\end{tabular}

Notes: The table reports OLS estimates controlling for grade size, language spoken at home in Wave 1, grade-gender fixed effects, and school-gender fixed effects. Standard errors (in brackets) are clustered at the school level. $* p<.10$, ** $p<.05$, $* * * p<.01 * p<.10, * * p<.05, * * * p<.01$

Table 3 reports results indicating that a higher Black share in a grade increases social contact with Blacks. In columns (1) and (3), we show that more Blacks in 
a grade within a school translates into a higher share of classmates who are Black in school both measured at Wave 1 in 1994-95 and at Wave 2 in 1996. ${ }^{9}$ Note that, while positive, the coefficient is significantly different from 1 , suggesting that blacks and whites are not equally distributed across classes within schools, possibly related to tracking or subject choice. Nonetheless, even if we restrict to the set of classmates which each person shares the most classes with (in column 5), we still find a significant impact here. Similarly, in column (7) we show that more Blacks in a grade also translates into a higher share of nominated friends. Columns (2), (4), (6) and (8) then show that these results are generally driven by Black peers of the same gender as the respondent. These results are in line with those reported in Merlino et al. (2019), and are consistent with the broader literature that shows young people form closer friendships with individuals of their own gender (McPherson et al., 2001; Kalmijn, 2002; Soetevent and Kooreman, 2007). Correspondingly, we find that $70 \%$ of closest friends in Wave 1 are of the same gender, and $76 \%$ of closest friends who are in the same grade are of the same gender. ${ }^{10}$

An important point highlighted by these results is that, although the variation we have is simply driven by random variation, it is enough to generate large impacts in interactions with Blacks for some White students. In other words, rather than thinking of as a $10 \%$ increase in the grade Black share as uniformly increasing everyone's contact with Blacks by $10 \%$, it is likely that some share of the White students experience a large increase in exposure. This may be the change, for instance, in going from no Black friends to having one Black friend. As a result, it is reasonable to hypothesize that there could be a large impact on the attitudes and behavior of those most effected by the change in cohort composition.

Table 4 reports the main result of the paper: more exposure to Blacks in school

\footnotetext{
${ }^{9}$ Note that data on classes taken is only collected for a subset of schools, substantially reducing our sample. The in-school survey is only conducted in Wave 1 and therefore all grade Black shares are measured in 1994-95. We use outcomes in Wave 1 for columns (5)-(8), but results are very similar if we run the same exercise for Wave 2. Moreover, results on friends remain very similar if we restrict to 'closest' friends, i.e. those they report having most contact with. Results available upon request.

${ }^{10}$ Note also that our results are compatible with the existence of homophily in friendship found by Currarini et al. (2009) and Fletcher et al. (2020). While that measure of homophily compares realized friendships with each group's share in the population of pupils, here we are interested in whether more diversity in the classroom implies more contact with Blacks in an absolute sense.
} 
has an impact on long-term residential choices. In particular, column (1) shows that individuals who were in grades with more Black students in 1994-95 are more likely to live in neighborhoods with more Blacks in 2016-18. Column (2) then shows that this effect is driven by Black peers of the same gender, in line with the results related to exposure shown in Table 3.

Table 4: Results on residential segregation in Wave 5

\begin{tabular}{|c|c|c|c|c|c|c|}
\hline & \multicolumn{2}{|c|}{$\begin{array}{c}\text { Black share } \\
\text { in census tract, } \\
\text { Wave } 5\end{array}$} & \multicolumn{2}{|c|}{$\begin{array}{l}\text { Black share } \\
>10 \%, \\
\text { Wave } 5\end{array}$} & \multicolumn{2}{|c|}{$\begin{array}{l}\text { Black share } \\
>20 \% \\
\text { Wave } 5\end{array}$} \\
\hline & (1) & (2) & (3) & (4) & (5) & (6) \\
\hline $\begin{array}{l}\text { Grade Black share, } \\
\text { both genders }\end{array}$ & $\begin{array}{l}0.189^{* *} \\
(0.0746)\end{array}$ & & $\begin{array}{l}0.588^{*} \\
(0.309)\end{array}$ & & $\begin{array}{l}0.427^{* *} \\
(0.190)\end{array}$ & \\
\hline $\begin{array}{l}\text { Grade Black share, } \\
\text { same gender }\end{array}$ & & $\begin{array}{l}0.194^{* * *} \\
(0.0565)\end{array}$ & & $\begin{array}{l}0.454^{* *} \\
(0.197)\end{array}$ & & $\begin{array}{l}0.415^{* *} \\
(0.159)\end{array}$ \\
\hline $\begin{array}{l}\text { Grade Black share, } \\
\text { opposite gender }\end{array}$ & & $\begin{array}{c}0.0109 \\
(0.0557)\end{array}$ & & $\begin{array}{c}0.219 \\
(0.286)\end{array}$ & & $\begin{array}{r}0.00913 \\
(0.108)\end{array}$ \\
\hline Observations & 7090 & 7090 & 7090 & 7090 & 7090 & 7090 \\
\hline Adjusted $\mathrm{R}^{2}$ & 0.188 & 0.189 & 0.149 & 0.149 & 0.141 & 0.141 \\
\hline Dep. var mean & 0.0819 & 0.0819 & 0.253 & 0.253 & 0.118 & 0.118 \\
\hline
\end{tabular}

Notes: The table reports OLS estimates controlling for grade size, language spoken at home in Wave 1, grade-gender fixed effects, and school-gender fixed effects. Standard errors (in brackets) are clustered at the school level. $* p<.10, * * p<.05$, $* * * \quad p<.01$

Figure 1 presents a version of our main result in a graphical fashion by plotting the relative share of Blacks in the (Wave 5) neighborhood of Whites against the relative share of Blacks in the (Wave 1) same gender cohort. The figure depicts a positive relationship which can be interpreted as follows: individual who are in a grade with more Black students of their gender with respect to their school average, also end up living in Blacker neighborhoods in Wave $\mathrm{V}$ than their schoolmates.

In terms of magnitude, the point estimate in column 2 of Table 4 implies that going from the average of 8 percent Blacks in the same gender cohort to 10 percent (an increase of around one within-school standard deviation) would increase the share of Blacks in one's neighborhood in Wave 5 by almost 0.4 percentage points, which is 5 percent of the mean.

To better understand the nature of these findings, we construct dummy vari- 
Figure 1: Correlation of relative shares, same sex cohort

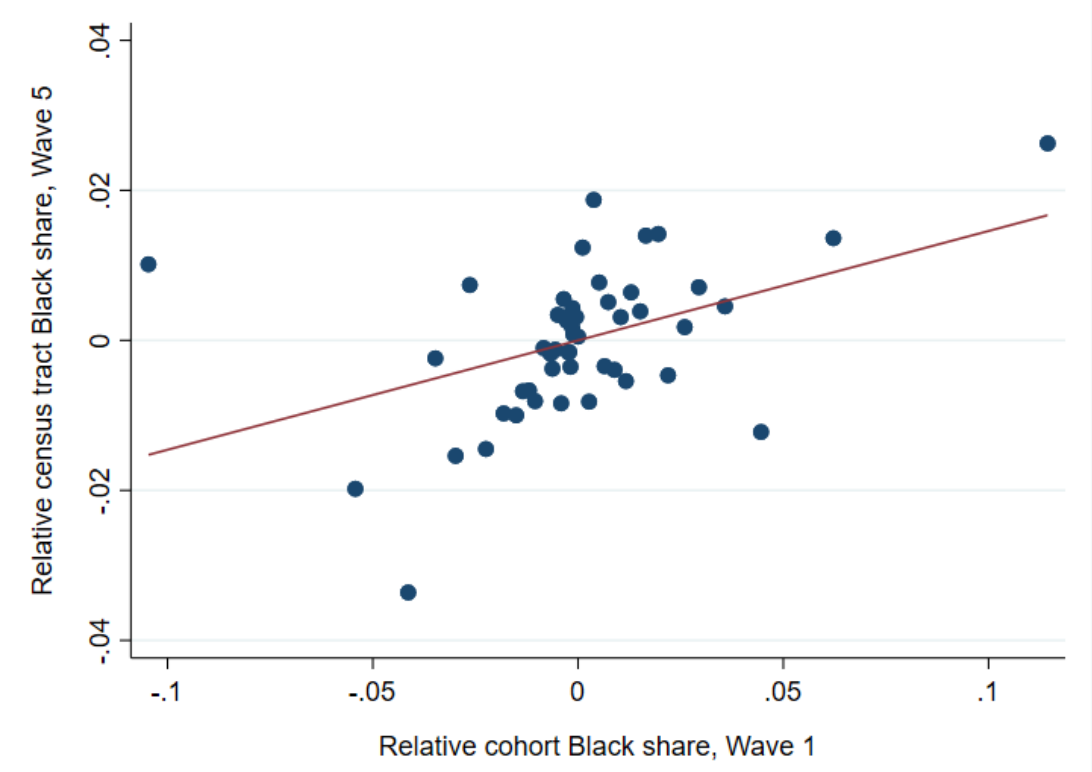

Notes: The figure plots a binned scatter plot of the relative share of Blacks in the Wave 5 neighborhood against the relative share of Blacks in the Wave 1 same gender cohorts. A cohort's relative Black share is the share within the cohort minus the minus the median of this variable among those in our sample who attended the same school. Individuals are binned into 50 bins of equal size according to their relative cohort Black share in Wave 1.

ables that take the value one if the individual resides in a neighborhood where the share of Blacks in 2016-18 is above a certain threshold. We then use the variables corresponding to the $10 \%$ and $20 \%$ thresholds as dependent variables in columns (3) to (6). The significant coefficients suggest that a large part of the main result is being driven by pushing White individuals to choose neighborhoods over these thresholds. This is particularly interesting in light of the findings of Card et al. (2008) confirming Schelling (1971)'s theory and according to which the tipping points above which Whites leave a neighborhood range from 5\% to $20 \%$.

To elaborate further on this point, we plot in Figure 2 the results of regressions where a dummy variable is constructed for different values of the share of Blacks in the neighborhood in Wave 5, ranging from to 0 to $100 \%$. The figure shows an inverted U-shape pattern, indicating that the effect is particularly strong for values around 10 to $20 \%$, even though the average Black share in our sample is only $8 \%$ (the full distribution is plotted in Figure B4). This suggests that the impact of social 
contact is particular relevant for Whites that might live in neighborhoods which would be considered as having a large potential for White flight behavior.

Figure 2: Impact across the distribution

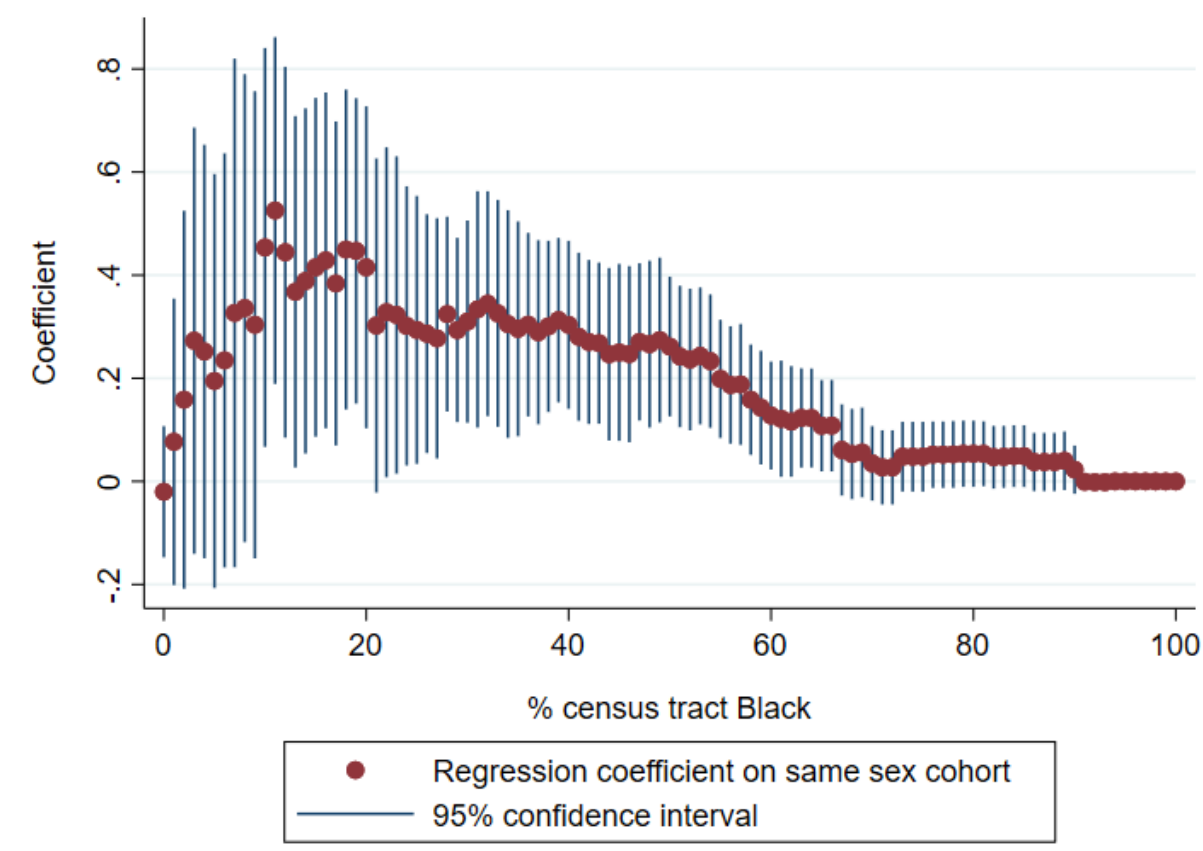

Notes: The figure plots OLS coefficients and $95 \%$ confidence intervals of the same gender grade Black share when we use as an outcome variable a dummy that takes the value one if the respondent lives in Wave 5 in a neighborhood with more than $\mathrm{x} \%$ Blacks (for different values of $\mathrm{x}$, represented on the horizontal axis). The regressions control for grade size, language spoken at home in Wave 1, grade-gender fixed effects, and school-gender fixed effects.

Table 5 provides evidence of the robustness of our preferred specification, namely column (2) in Table 4. We report this result again in column (1) of Table 5 and then add in various sets of controls to observe how our coefficient of interest changes. In column (2), we include several individual controls measured in Wave 1, including family income, mother's education, and the Black share of the census tract. We explicitly show the coefficient on the census tract Black share in the table as it could be interesting to compare its magnitude with our identified effect. Doing so, shows that the coefficient of an individual's census tract Black share has less than half of the size of our main coefficient of interest. Column (3) additionally includes other characteristics of the Wave 1 cohort, including the share of the same gender cohort whose mother attended college and the share born in the US. Our coefficient of 
interest remains almost unchanged, suggesting that our result is not being driven by unobservables correlated with the controls we add (Altonji et al., 2005; Oster, 2019).

We can additionally control for a number of unobservables by introducing school trends and other fixed effects. In column (4), we control for school-specific trends, and in column (5) for school-grade fixed effects. The most demanding specification is probably that of column (6), where we additionally include fixed effects for the tract of residence in Wave 1 . Note that, there are on average 25 census tracts within a school. By including census tract fixed effects, we are controlling for any difference in the residential area from which students are drawn. Indeed, neighborhood characteristics when young have been shown in the literature to be correlated with residential preferences in adulthood (Dawkins, 2005). The results reported in Table 5 show that the coefficients are relatively stable in these specifications, if not slightly stronger. In Table E15, we show that results are also largely unchanged if we control for Black shares in adjacent cohorts.

Since we have strong evidence that our variation in cohort same gender Black share is quasi-random and race is generally not measured with error, selection bias or measurement error is unlikely to be a problem here. This point is discussed further in Appendix D.

Some individuals surveyed in Wave 1 are not part of the final sample as they were not interviewed in Wave 5, and hence one may be concerned that this attrition impacts the results. In Appendix A, we show that this is unlikely to be the case. First, we show that, in our sample, the Black share of one's same gender cohort is not related to attrition. Furthermore, our results are robust to taking into account survey weights provided by Add Health for panel analysis on Waves 1 and 5, which control for attrition based on observables. We also show that our results are improved by the inclusion of individuals who didn't initially respond to the Wave 5 survey, which is comforting if we believe they may be more like non-responders than the rest of the sample. Finally, in column 5 of Table D14, we show that our result is robust to removing individuals who are in grade 12 in Wave 1, since we may be concerned that variation in black share measured here is a function of differential dropout rates. 
Table 5: Robustness analysis

\begin{tabular}{|c|c|c|c|c|c|c|}
\hline & (1) & (2) & (3) & (4) & (5) & (6) \\
\hline $\begin{array}{l}\text { Grade Black share, } \\
\text { same gender }\end{array}$ & $\begin{array}{l}0.194^{* * *} \\
(0.0565)\end{array}$ & $\begin{array}{l}0.195^{* * *} \\
(0.0511)\end{array}$ & $\begin{array}{l}0.181^{* * *} \\
(0.0515)\end{array}$ & $\begin{array}{l}0.196^{* *} \\
(0.0822)\end{array}$ & $\begin{array}{l}0.263^{* * *} \\
(0.0980)\end{array}$ & $\begin{array}{r}0.291^{* * *} \\
(0.104)\end{array}$ \\
\hline $\begin{array}{l}\text { Grade Black share, } \\
\text { opposite gender }\end{array}$ & $\begin{array}{c}0.0109 \\
(0.0557)\end{array}$ & $\begin{array}{l}0.00861 \\
(0.0518)\end{array}$ & $\begin{array}{l}0.00910 \\
(0.0525)\end{array}$ & $\begin{array}{l}-0.0148 \\
(0.0631)\end{array}$ & & \\
\hline $\begin{array}{l}\text { Census tract Black } \\
\text { share, wave } 1\end{array}$ & & $\begin{array}{l}0.0892^{* *} \\
(0.0358)\end{array}$ & $\begin{array}{l}0.0884^{* *} \\
(0.0356)\end{array}$ & $\begin{array}{r}0.0954^{* * *} \\
(0.0358)\end{array}$ & $\begin{array}{l}0.0846^{* *} \\
(0.0357)\end{array}$ & \\
\hline Extended controls & & $\mathrm{Y}$ & $\mathrm{Y}$ & $\mathrm{Y}$ & $\mathrm{Y}$ & $\mathrm{Y}$ \\
\hline $\begin{array}{l}\text { Extended cohort } \\
\text { controls }\end{array}$ & & & $\mathrm{Y}$ & $\mathrm{Y}$ & $\mathrm{Y}$ & $\mathrm{Y}$ \\
\hline School trends & & & & $\mathrm{Y}$ & & \\
\hline School-grade FE & & & & & $\mathrm{Y}$ & $\mathrm{Y}$ \\
\hline Tract FE & & & & & & $\mathrm{Y}$ \\
\hline Observations & 7090 & 7090 & 7090 & 7090 & 7078 & 6564 \\
\hline Adjusted $R^{2}$ & 0.189 & 0.203 & 0.203 & 0.207 & 0.185 & 0.187 \\
\hline
\end{tabular}

Notes: The table reports OLS estimates. The dependent variable is the Black share of the Wave $\mathrm{V}$ census tract population. Benchmark controls included in all columns are grade size, language spoken at home in Wave 1, grade-gender fixed effects, and school-gender fixed effects. Extended controls include an individual's religion, birth year, the Black share of the census block group, whether an individual lived with a single parent at Wave 1, whether an individual had repeated or skipped a grade prior to Wave 1, family income, mother's education, whether an individual was born in the US and the individual's age at Wave 5. Extended cohort controls include the share of the same gender cohort whose mother attended college, the share whose father attended college, the share Hispanic, the share Asian, the share whose parents were born in the US, and the share the same gender. Standard errors (in brackets) are clustered at the school level. $* p<.10, * * p<.05$, *** $p<.01$

Another concern is that, since our identification is driven by small quasi-random variation across cohorts, our results may be driven by some other aspect of the cohort which is correlated with the Black shares. We test for this in two ways. First, we construct over two hundred other cohort shares including, for instance, the share of Hispanics and the share who have college educated mothers. We enter them into regressions individually in place of our main explanatory variable and record the t-statistic. In doing so, we obtain a distribution of the t-statistic of the different coefficients. Figure E6 in Appendix E clearly shows that the t-statistic of our coefficient of interest is an outlier on the right tail of this distribution. Second, we perform ten thousand placebo regressions in which we assign students to cohorts within their school at random. Plotting the distribution of coefficients, we note that the true coefficient is clearly an outlier as it is larger than almost all of the 
placebo coefficients (see Figure E7 in Appendix E). We can therefore conclude that it is very unlikely that our results are driven by chance or correlation with other characteristics of school cohorts.

In Appendix F, we investigate some subsample splits and interactions to further investigate the nature of our results. The estimates show that the coefficient of interest does not significantly differ by gender, and we find no significant interactions when interacting our coefficient of interest with the school Black share, withinschool friendship segregation, the Republican vote share in the school county, the share of students residing in urban areas, or the grade size reveals. This is likely to be the result of a lack of power rather than strong evidence for a homogeneous effect. One area we do find a significant difference in is region, with a significantly smaller effect for the subsample of schools in the North East region. One potential explanation for this is that this is the region where, in our sample, within-county Black-White segregation appears smallest, but this result should be interpreted with caution given that the survey is not representative at the regional level. Finally, in Table F18 we do not find any evidence that the result is driven by Blacks of a particular 'type' - e.g., those scoring grades above average. This speaks in favor of a general impact of exposure which is independent of any individual characteristics of Blacks. This result is noteworthy as studies on older individuals-i.e., in college - found the impact of minority exposure to vary with the ability of minority students (e.g., Carrell et al., 2019). Again, however, lack of power prevents us from concluding that such an effect couldn't be present here.

In the next section, we turn to exploring the mechanisms behind our findings exploiting the richness of the Add Health data.

\section{Investigating Mechanisms}

The literature on residential segregation has emphasized one major factor that could explain our results: racial preferences (Boustan, 2011). In the context of our paper, there are two additional potentially relevant mechanisms: economic opportunities and residential choices of friends or partners. In the remainder of this section, we will review the various mechanisms to qualify our results and discuss potential 
drivers.

\subsection{Economic Opportunities}

Some studies have found that an increased share of Black students in school can worsen the educational achievement for their peers (Hoxby, 2000; Hanushek et al., 2009; Billings et al., 2014). This may translate in the long run into worse labor market outcomes. This would then limit one's ability to move to more amenable neighborhoods, which are more expensive and characterized by relatively fewer Black residents.

To test for this mechanism, we first analyze whether we observe any impact of cohort Black shares on average test scores, college attendance, employment, earnings, or criminal activity (as recorded by being arrested or incarcerated). The results of these regressions are presented in Table 6. The coefficients on the Black shares are always insignificant. This is consistent with Bifulco et al. (2011) and Merlino et al. (2019), who do not find any impact of minority shares on these outcomes in Waves 3 and 4. Hence, there is no support for the hypothesis that contact with Blacks in school translates into sufficiently lower opportunities which induce changes in residential location due to financial constraints.

Table 6: Other outcomes related to education, employment, and criminality

\begin{tabular}{lcccccc}
\hline & $\begin{array}{c}\text { Average } \\
\text { test score } \\
(1)\end{array}$ & $\begin{array}{c}\text { Attended } \\
\text { college } \\
(2)\end{array}$ & $\begin{array}{c}\text { Employed } \\
(3)\end{array}$ & $\begin{array}{c}\text { Log } \\
\text { earnings } \\
(4)\end{array}$ & $\begin{array}{c}\text { Ever } \\
\text { arrested } \\
(5)\end{array}$ & $\begin{array}{c}\text { Ever } \\
\text { incarcerated } \\
(6)\end{array}$ \\
\hline Grade Black share, & 0.384 & -0.0318 & -0.00897 & 0.687 & 0.131 & 0.0355 \\
same gender & $(0.337)$ & $(0.172)$ & $(0.119)$ & $(0.804)$ & $(0.178)$ & $(0.121)$ \\
Grade Black share, & -0.0690 & -0.00445 & 0.209 & -0.163 & 0.0346 & -0.0605 \\
opposite gender & $(0.414)$ & $(0.180)$ & $(0.160)$ & $(0.616)$ & $(0.205)$ & $(0.133)$ \\
\hline Observations & 7003 & 7090 & 7090 & 6762 & 6998 & 6992 \\
Adjusted R & 0.107 & 0.0870 & 0.0501 & 0.0317 & 0.0830 & 0.0620 \\
Dep. var mean & 2.890 & 0.643 & 0.843 & 10.20 & 0.278 & 0.114 \\
\hline
\end{tabular}

Notes: The table reports OLS estimates controlling for grade size, language spoken at home in Wave 1, grade-gender fixed effects, and school-gender fixed effects. The dependent variables are all measured in Wave 5. Standard errors (in brackets) are clustered at the school level. * $p<.10,{ }^{* *} p<.05, * * * p<.01$

Another way to test for this hypothesis is to look at the neighborhood characteristics in Wave 5. If treated individuals are more likely to live in Blacker areas 
because of financial constraints, we should expect their neighborhoods to be worse than others along an array of other dimensions such as population density, average income, poverty rates, unemployment, or the share of inhabitants with a college degree. Table 7 finds no evidence that exposure to Blacks in school has an impact on any of these characteristics of one's (tract-level) neighborhood. It therefore appears unlikely that our result is driven by changes in the economic opportunities available to Whites.

Table 7: Other tract characteristics

\begin{tabular}{lcccccc}
\hline & $\begin{array}{c}\text { Log pop. } \\
\text { density } \\
(1)\end{array}$ & $\begin{array}{c}\text { Log of } \\
\text { median income } \\
(2)\end{array}$ & $\begin{array}{c}\text { Poverty } \\
\text { rate } \\
(3)\end{array}$ & $\begin{array}{c}\text { Unemployment } \\
\text { rate } \\
(4)\end{array}$ & $\begin{array}{c}\text { Share college } \\
\text { degree } \\
(5)\end{array}$ & $\begin{array}{c}\text { Log of median } \\
\text { property value } \\
(6)\end{array}$ \\
\hline $\begin{array}{l}\text { Grade Black share, } \\
\text { same gender }\end{array}$ & 0.119 & -0.0241 & 0.0304 & 0.0144 & 0.0614 & -0.0602 \\
& $(1.026)$ & $(0.194)$ & $(0.0486)$ & $(0.0139)$ & $(0.0732)$ & $(0.325)$ \\
Grade Black share, & -1.434 & 0.0730 & -0.000717 & 0.00112 & -0.0150 & -0.295 \\
opposite gender & $(0.909)$ & $(0.162)$ & $(0.0356)$ & $(0.0178)$ & $(0.0783)$ & $(0.350)$ \\
\hline Observations & 7090 & 7088 & 7089 & 7090 & 7090 & 7090 \\
Adjusted R & 0.330 & 0.231 & 0.182 & 0.121 & 0.227 & 0.330 \\
Dep. var mean & 6.038 & 11.065 & 0.117 & 0.055 & 0.318 & 12.239 \\
\hline
\end{tabular}

Notes: The table reports OLS estimates controlling for grade size, language spoken at home in Wave 1, grade-gender fixed effects, and school-gender fixed effects. The dependent variables are all taken from the American Community Survey and linked to Wave 5 Add Health data. Standard errors (in brackets) are clustered at the school level. $* p<.10$, ** $p<.05$, *** $p<.01$

\subsection{Social Networks and Partners}

An alternative explanation is that the effect we find on residential segregation is driven by social networks, in particular through the residential choices of Black friends made in school. One way to test for this mechanism is to analyze how the effect varies over time and space. The idea is that social connections formed in school tend to weaken over time and space, because as time passes by and individuals move further away, they tend to see each other less. As a result, if the main mechanism behind our results were related to friendships and social ties formed in school, we should expect our results to be stronger when the respondent is closer in time and space to the exposure to Blacks in school.

To explore the time dimension, we plot in Figure 3 our main coefficient of interest on the same gender grade Black share across different waves of the survey. 
Moreover, we distinguish between census tracts and counties. The first interesting result to report is that the effect of school diversity on residential choices in census tracts emerges between Waves 3 and Wave 5, i.e., many years after exposure and not right after leaving high school. This pattern is not consistent with the idea that people chose their residential location to stay closer to their high-school friends, who happened to be more likely to be Blacks for individuals more exposed to Blacks in school.

Figure 3: Impact on tract and county Black shares over time

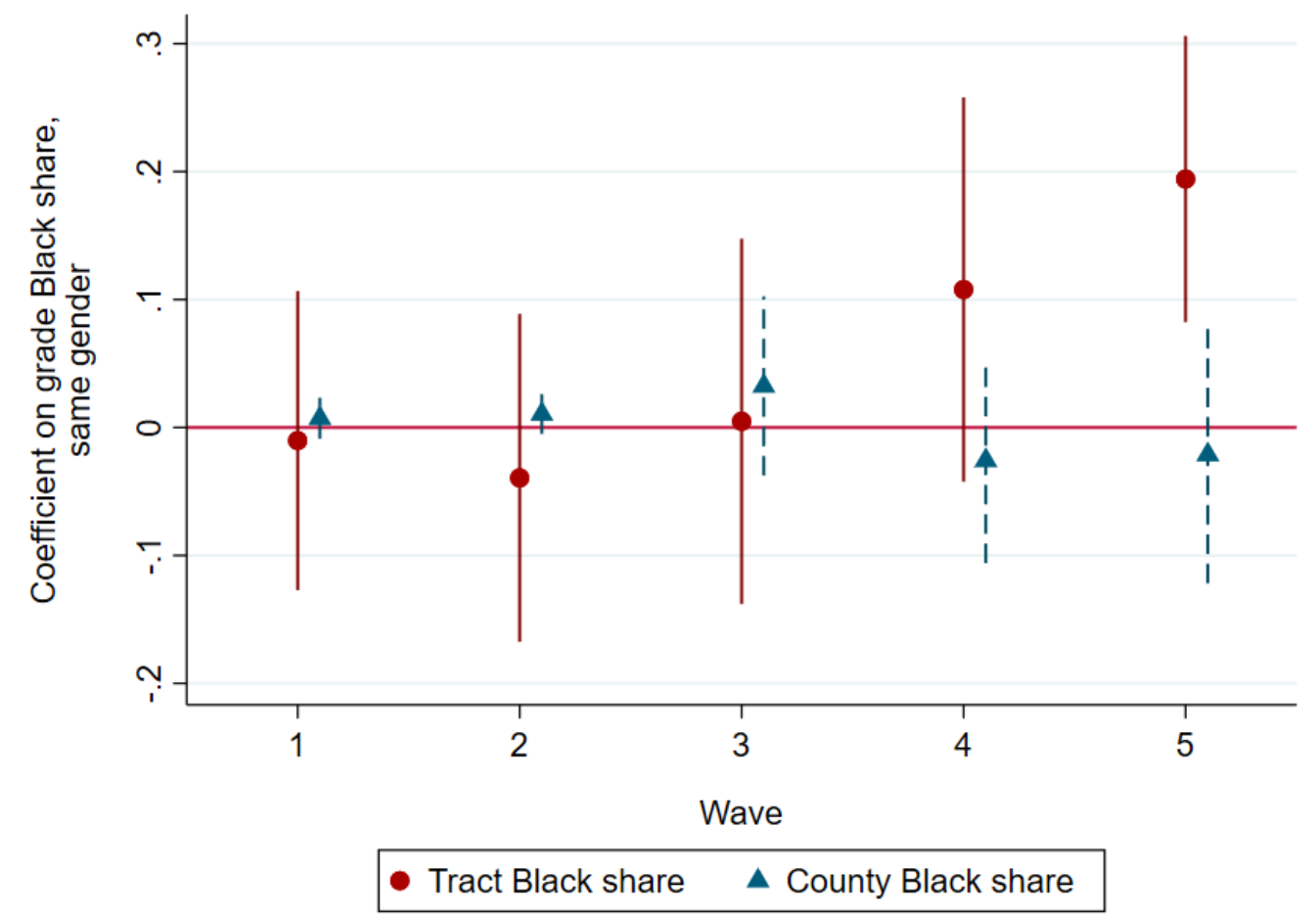

Notes: The figure plots reports OLS coefficients and 95\% confidence intervals of the same gender grade Black share from regressions where the dependent variable is the share of Blacks in the census tract (in red) and county (in blue). Regressions control for grade size, language spoken at home in Wave 1, grade-gender fixed effects, and school-gender fixed effects.

The second notable pattern is that we do not find a statistically significant effect for counties at any point in time. This is not surprising as long-distance moves across counties and state are primarily driven by job related reasons (Molloy and Smith, 2019; Ning et al., 2022) for which local racial composition should not matter. For moves within counties, which are dominated by housing and family motives 
(Molloy and Smith, 2019; Ning et al., 2022), we instead find that racial composition plays a role in later waves.

Finally, it is noteworthy that exposure to Blacks during childhood does not affect residential choices immediately after school (Wave 3) when location changes often reflect educational choices or the transition into the labor market. Instead, we find exposure to matter most in Wave 5 when respondents are between 33 and 43 years old. This age group belongs to the so-called category of "family age" adults for whom location changes are often driven by family-related motives such as marriage, children, or schooling (DeWaard et al., 2019). Consistent with this interpretation, in Appendix $\mathrm{G}$ we find the correlation between tract Black share and stated liberalness to be strongest in Wave 5, suggesting that it is at this point of the life-cycle when attitudes are most likely to play an important role in residential choices.

To explore the geographical dimension, we analyze whether our effect is significantly different for those who have moved further away from their school location. Doing so, we find in column (1) of Table 8 that the effect of exposure does not vary with the distance moved between Wave 1 and Wave 5. Again, this appears inconsistent with the idea that our result is driven by a desire to be close to school friends.

An alternative possibility is that residential choices could be due to the preferences of Black partners of White respondents. This possibility could conceivably contribute to the main result since we have shown in previous work that social contact with Blacks in school translates into a higher probability of having an interracial relationship later on in life (Merlino et al., 2019). However, column (2) of Table 8 does not support this view, as we do not find evidence that the effect differs between respondents who have no Black partner and those with a Black partner in Wave 5. Moreover, given that having a Black partner is relatively rare, this mechanism would unlikely be able to explain a large share of our main result.

\subsection{Racial Preferences}

Having ruled out these alternative channels, the remaining likely potential mechanism is a change in preferences. Unfortunately, there are no direct measures of 
racial attitudes in the Add Health survey. However, in Table 8 we analyze some variables that could be attributed to changes in attitudes.

First, although racial attitudes are not measured directly, there are some measures which we might believe are correlated with racial attitudes. In Waves 4 and 5 , for instance, respondents are asked whether they consider themselves politically liberal. Since these waves occur at times when race was a potentially salient political issue, it is possible that part of people's responses to these questions may be impacted by their attitudes towards Blacks. ${ }^{11}$ In Wave 3, respondents were asked whether race is an important factor within a romantic relationship, which again could be correlated with more general attitudes towards Blacks. To increase power, we combine these three measures of stated liberalness into a standardized index using inverse covariance weighting and put it as the dependent variable in our baseline regression in column 3 of Table $8 .{ }^{12}$ In column 4 of this table, we also test whether more exposed individuals are more likely to have a Black partner, which again is likely to be correlated with attitudes towards Blacks. Consistent with Merlino et al. (2019), we find significant positive impacts on both of these outcomes.

As a further test of whether changes in preferences are a consistent mechanism for the impact we find, we can explore whether there is any impact of school exposure on outcomes related to White flight. This concept describes the phenomenon that Whites are more likely to move out of neighborhoods when there are more Blacks living there, and has been found to be an important determinant of residential segregation (Reber, 2005; Card et al., 2008; Lee, 2017). In columns 5 and 6, we therefore explore the correlation between a neighborhood's relative Black share and two outcomes related to White flight. ${ }^{13}$ Consistent with the process of White

\footnotetext{
${ }^{11}$ Wave 4 was undertaken at a time when Obama was running for and then became the first Black US president, while Wave 5 took place in 2016-2018 when racial issues were at the center of Trump's presidential campaign (Henderson, 2016).

${ }^{12}$ See Appendix $\mathrm{G}$ for regressions with the individual index components and discussion of how the index varies with residential location across waves.

${ }^{13}$ The relative tract Black share is defined as the Black share of the census tract where an individual lives in the relevant wave, minus the median census tract Black share of others in our sample from the same school. We use this relative share as a proxy of how Black a neighborhood is compared to other neighborhoods where the individual could most likely move to. Note that the number of observations in these columns is smaller than the full sample since in column 5 we restrict to those who responded in Wave 2 (the latest wave in which these questions were asked), and in column 6 we
} 
flight, we find that Whites in neighborhoods with a higher Black share are less satisfied with their neighborhood and typically move further between Waves 3 and 5 (when the impact of school contact on residential choices emerges). Most interestingly, the interactions of same gender Black share and the relative tract Black share in both columns show a strong negative sign. Hence, we find that these White flight patterns are weaker for people who had more Blacks of the same gender in their school grade. In other words, for Whites more exposed to Blacks at school, their neighborhood satisfaction and subsequent moving behavior is less negatively correlated with the neighborhood Black share.

Altogether, these findings support the interpretation that individuals who had more contact with Blacks in school are more likely to live in racially mixed neighborhoods due to a change in racial preferences.

restrict to those on which we have the Wave 3 location information. The neighborhood satisfaction index is constructed using seven questions related to an individual's neighborhood—see Appendix $\mathrm{G}$ for more details and results using the individual components. 
Table 8: Results relating to social networks and preferences

\begin{tabular}{|c|c|c|c|c|c|c|}
\hline & \multicolumn{2}{|c|}{$\begin{array}{c}\text { Cenus tract } \\
\text { Black share, } \\
\text { wave } 5\end{array}$} & \multirow{2}{*}{$\begin{array}{c}\text { Stated } \\
\text { liberal- } \\
\text { ness } \\
\text { index } \\
(3)\end{array}$} & \multirow{2}{*}{$\begin{array}{c}\text { Has } \\
\text { Black } \\
\text { partner, } \\
\text { wave } 5 \\
(4)\end{array}$} & \multirow[t]{2}{*}{$\begin{array}{c}\text { N'hood } \\
\text { satis- } \\
\text { faction } \\
\text { index, } \\
\text { wave } 2 \\
(5)\end{array}$} & \multirow{2}{*}{$\begin{array}{c}\text { Log of } \\
\text { km } \\
\text { moved, } \\
\text { waves 3-5 } \\
\text { (6) }\end{array}$} \\
\hline & (1) & (2) & & & & \\
\hline $\begin{array}{l}\text { Grade Black share, } \\
\text { same gender }(\mathrm{S})\end{array}$ & $\begin{array}{l}0.298^{*} \\
(0.151)\end{array}$ & $\begin{array}{l}0.185^{* * *} \\
(0.0589)\end{array}$ & $\begin{array}{l}0.742^{*} \\
(0.444)\end{array}$ & $\begin{array}{l}0.180^{* *} \\
(0.0902)\end{array}$ & $\begin{array}{l}0.0287 \\
(0.437)\end{array}$ & $\begin{array}{l}-0.587 \\
(1.519)\end{array}$ \\
\hline $\begin{array}{l}\text { Grade Black share, } \\
\text { opposite gender }(\mathrm{O})\end{array}$ & $\begin{array}{c}0.0578 \\
(0.0947)\end{array}$ & $\begin{array}{c}0.0236 \\
(0.0534)\end{array}$ & $\begin{array}{l}-0.171 \\
(0.364)\end{array}$ & $\begin{array}{l}-0.0314 \\
(0.0758)\end{array}$ & $\begin{array}{l}0.0542 \\
(0.468)\end{array}$ & $\begin{array}{c}0.760 \\
(0.974)\end{array}$ \\
\hline $\begin{array}{l}\text { Log of } \mathrm{km} \text { moved, } \\
\text { waves } 1-5(\mathrm{D})\end{array}$ & $\begin{array}{c}0.00471 \\
(0.00351)\end{array}$ & & & & & \\
\hline $\mathrm{S} \times \mathrm{D}$ & $\begin{array}{l}-0.0258 \\
(0.0355)\end{array}$ & & & & & \\
\hline $\mathrm{O} \times \mathrm{D}$ & $\begin{array}{l}-0.0103 \\
(0.0208)\end{array}$ & & & & & \\
\hline $\begin{array}{l}\text { Has Black partner, } \\
\text { wave } 5(\mathrm{P})\end{array}$ & & $\begin{array}{l}-0.0651 \\
(0.0630)\end{array}$ & & & & \\
\hline $\mathrm{S} \times \mathrm{P}$ & & $\begin{array}{c}0.125 \\
(0.456)\end{array}$ & & & & \\
\hline $\mathrm{O} \times \mathrm{P}$ & & $\begin{array}{l}-0.0886 \\
(0.904)\end{array}$ & & & & \\
\hline $\begin{array}{l}\text { Relative tract Black } \\
\text { share }(R)\end{array}$ & & & & & $\begin{array}{c}-6.529^{* * *} \\
(0.635)\end{array}$ & $\begin{array}{l}8.203^{* * *} \\
(0.915)\end{array}$ \\
\hline $\mathrm{S} \times \mathrm{R}$ & & & & & $\begin{array}{l}11.66^{* * *} \\
(3.992)\end{array}$ & $\begin{array}{l}-20.86^{* *} \\
(8.092)\end{array}$ \\
\hline $\mathrm{O} \times \mathrm{R}$ & & & & & $\begin{array}{c}7.007 \\
(5.446)\end{array}$ & $\begin{array}{c}1.512 \\
(7.336)\end{array}$ \\
\hline School FEs $\times$ D & $\mathrm{Y}$ & & & & & \\
\hline School FEs $\times$ P & & $\mathrm{Y}$ & & & & \\
\hline School FEs $\times$ R & & & & & $\mathrm{Y}$ & $\mathrm{Y}$ \\
\hline Observations & 7060 & 7090 & 7090 & 7090 & 5330 & 5843 \\
\hline Adjusted $\mathrm{R}^{2}$ & 0.25 & 0.22 & 0.11 & 0.04 & 0.09 & 0.09 \\
\hline Dep. var mean & 0.08 & 0.08 & -0.00 & 0.02 & 0.00 & 3.52 \\
\hline
\end{tabular}




\section{Conclusions}

In this paper, we analyze how variation across White students' school peer groups affects residential location choices in adulthood. We exploit idiosyncratic variation in grade composition within schools, and we provide several tests supporting the assumption that the variation used is as good as random. We then show that a greater share of Blacks within White students' school cohorts in 1994-95 leads them to reside in neighborhoods with more Blacks in 2016-18. This result is driven by Black peers of the same gender as the respondent, who we show individuals are likely to have more interactions with than those of the opposite gender.

Our findings suggest that economic opportunities, partner preferences in interracial relationships, and social networks are unlikely to be major forces behind these results. Indeed, we find no effect of cohort racial composition on individual education and labor market outcomes, nor on neighborhood characteristics such as average income, crime, or property value. Instead, the most likely mechanism behind our results is a change in racial preferences of respondents.

With respect to policy, our analysis suggests that being exposed to Black students in school can translate into a reduction of White flight behavior, which is an important driver of racial segregation in the US (Boustan, 2010; Shertzer and Walsh, 2019). Therefore, policies aiming to increase racial diversity in schools, such as redesigning school attendance boundaries, could help to reduce racial segregation and its negative welfare effects among future generations. If such policies result in large changes in racial compositions, however, they may also trigger more segregation in school (Currarini et al., 2009) or changes in school choice (Monarrez, 2022). The results in this paper suggest that inducing smaller variations might provide a way to solve the potential trade-offs between school choice in the short-run and long-run behavior. However, more work is needed to better understand these trade-offs.

Finally, an additional important question is whether the results extend to other contexts. In Europe, for instance, various migrant communities experience important levels of residential segregation, and it would be interesting to explore whether childhood contact can have similar effects in this alternative setting where cultural differences are arguably larger. 


\section{References}

Abadie, Alberto, Susan Athey, Guido W Imbens, and Jeffrey M Wooldridge. 2022. When should you adjust standard errors for clustering? The Quarterly Journal of Economics 138(1): 1-35.

Aliprantis, Dionissi, Daniel R. Carroll, and Eric R. Young. 2022. What explains neighborhood sorting by income and race? Journal of Urban Economics, in press.

Allport, Gordon W. 1954. The nature of prejudice. New York: Addison.

Altonji, Joseph G, Todd E Elder, and Christopher R Taber. 2005. Selection on observed and unobserved variables: Assessing the effectiveness of catholic schools. Journal of Political Economy 113(1): 151-184.

Ananat, Elizabeth Oltmans. 2011. The wrong side(s) of the tracks: The causal effects of racial segregation on urban poverty and inequality. American Economic Journal: Applied Economics 3(2): 34-66.

Anderson, Michael L. 2008. Multiple inference and gender differences in the effects of early intervention: A reevaluation of the Abecedarian, Perry Preschool, and Early Training Projects. Journal of the American Statistical Association 103(484): 1481-1495.

Angrist, Joshua D. 2014. The perils of peer effects. Labour Economics 30: 98-108.

Baum-Snow, Nathaniel and Byron F. Lutz. 2011. School desegregation, school choice, and changes in residential location patterns by race. The American Economic Review 101(7): 3019-46.

Bayer, Patrick, Marcus D Casey, W Ben McCartney, John Orellana-Li, and Calvin S Zhang. 2022. Distinguishing causes of neighborhood racial change: A nearest neighbor design. NBER Working Paper 30487, NBER.

Bazzi, Samuel, Arya Gaduh, Alexander D Rothenberg, and Maisy Wong. 2019. Unity in diversity? How intergroup contact can foster nation building. The American Economic Review 109(11): 3978-4025.

Bifulco, Robert, Jason M Fletcher, and Stephen L Ross. 2011. The effect of classmate characteristics on post-secondary outcomes: Evidence from the Add Health. American Economic Journal: Economic Policy 3(1): 25-53. 
Billings, Stephen B, Eric Chyn, and Kareem Haggag. 2021. The long-run effects of school racial diversity on political identity. American Economic Review: Insights 3(3): 267-84.

Billings, Stephen B., David J. Deming, and Jonah Rockoff. 2014. School segregation, educational attainment, and crime: Evidence from the end of busing in Charlotte-Mecklenburg. The Quarterly Journal of Economics 129(1): 435-476.

Boucher, Vincent, Semih Tumen, Michael Vlassopoulos, Jackline Wahba, and Yves Zenou. 2021. Ethnic mixing in early childhood: Evidence from a randomized field experiment and a structural model. IZA Discussion Papers 14260, IZA.

Boustan, Leah. 2010. Was postwar suburbanization "white flight"? Evidence from the black migration. The Quarterly Journal of Economics 125(1): 417-443.

. 2011. Racial residential segregation in American cities. In Handbook of urban economics and planning, eds. Nancy Brooks, Kieran Donaghy, and Gerrit Knaap. Oxford University Press, 318-339.

- 2017. Competition in the promised land: Black migrants in northern cities and labor markets. Princeton University Press.

Bursztyn, Leonardo, Thomas Chaney, Tarek Alexander Hassan, and Aakaash Rao. 2021. The immigrant next door: Long-term contact, generosity, and prejudice. NBER Working Paper 28448, NBER.

Caeyers, Bet and Marcel Fafchamps. 2016. Exclusion bias in the estimation of peer effects. NBER Working Paper 22565, NBER.

Card, David, Alexandre Mas, and Jesse Rothstein. 2008. Tipping and the dynamics of segregation. The Quarterly Journal of Economics 123(1): 177-218.

Carrell, Scott E., Mark Hoekstra, and Elira Kuka. 2018. The long-run effects of disruptive peers. The American Economic Review 108(11): 3377-3415.

Carrell, Scott E., Mark Hoekstra, and James E. West. 2019. The impact of college diversity on behavior toward minorities. American Economic Journal: Economic Policy 11(4): 159-82.

Charles, Camille Zubrinsky. 2003. The dynamics of racial residential segregation. Annual Review of Sociology 29: 167-207. 
Corno, Lucia, Eliana La Ferrara, and Justine Burns. 2022. Interaction, stereotypes and performance. Evidence from South Africa. The American Economic Review 112(12): 3848-75.

Crowder, Kyle. 2000. The racial context of white mobility: An individual-level assessment of the white flight hypothesis. Social Science Research 29(2): 223257.

Currarini, Sergio, Matthew O Jackson, and Paolo Pin. 2009. An economic model of friendship: Homophily, minorities, and segregation. Econometrica 77(4): 10031045.

Cutler, David M, Edward L Glaeser, and Jacob L Vigdor. 1999. The rise and decline of the American ghetto. Journal of Political Economy 107(3): 455-506.

Dawkins, Casey J. 2005. Evidence on the intergenerational persistence of residential segregation by race. Urban Studies 42(3): 545-555.

Derenoncourt, Ellora. 2022. Can you move to opportunity? Evidence from the Great Migration. The American Economic Review 112(2): 369-408.

DeWaard, Jack, Janna Johnson, and Stephan Whitaker. 2019. Internal migration in the United States: A comprehensive comparative assessment of the Consumer Credit Panel. Demographic Research 41(33): 953-1006.

Echenique, Federico and Roland G Fryer. 2007. A measure of segregation based on social interactions. The Quarterly Journal of Economics 122(2): 441-485.

Fletcher, Jason M, Stephen L Ross, and Yuxiu Zhang. 2020. The consequences of friendships: Evidence on the effect of social relationships in school on academic achievement. Journal of Urban Economics 116: 103241.

Fruehwirth, Jane Cooley, Sriya Iyer, and Anwen Zhang. 2019. Religion and depression in adolescence. Journal of Political Economy 127(3): 1178-1209.

Gordon, Nora and Sarah Reber. 2018. The effects of school desegregation on mixed-race births. Journal of Population Economics 31(2): 561-596.

Guryan, Jonathan, Kory Kroft, and Matthew J Notowidigdo. 2009. Peer effects in the workplace: Evidence from random groupings in professional golf tournaments. American Economic Journal: Applied Economics 1(4): 34-68. 
Hanushek, Eric A, John F Kain, and Steven G Rivkin. 2009. New evidence about Brown v. Board of Education: The complex effects of school racial composition on achievement. Journal of Labor Economics 27(3): 349-383.

Henderson, Nia-Malika. 2016. Race and racism in the 2016 campaign. https://edition.cnn.com/2016/08/31/politics/2016-election-donald-trumphillary-clinton-race/index.html. Accessed: 2022-07-15.

Hill, Andrew J. 2015. The girl next door: The effect of opposite gender friends on high school achievement. American Economic Journal: Applied Economics 7(3): 147-177.

Hoxby, Caroline. 2000. Peer effects in the classroom: Learning from gender and race variation. NBER Working Paper 7867, NBER.

Kalmijn, Matthijs. 2002. Sex segregation of friendship networks. individual and structural determinants of having cross-sex friends. European Sociological Review 18(1): 101-117.

Lavy, Victor, M Daniele Paserman, and Analia Schlosser. 2012. Inside the black box of ability peer effects: Evidence from variation in the proportion of low achievers in the classroom. The Economic Journal 122(559): 208-237.

Lavy, Victor and Analia Schlosser. 2011. Mechanisms and impacts of gender peer effects at school. American Economic Journal: Applied Economics 3(2): 1-33.

Lee, Kwan Ok. 2017. Temporal dynamics of racial segregation in the United States: An analysis of household residential mobility. Journal of Urban Affairs 39(1): $40-67$.

Logan, John R. and Brian J. Stults. 2022. Metropolitan segregation: No breakthrough in sight. Working Papers 22-14, Center for Economic Studies, U.S. Census Bureau.

Logan, Trevon D. and John M. Parman. 2017. Segregation and homeownership in the early twentieth century. The American Economic Review 107(5): 410-14.

Lowe, Matt. 2021. Types of contact: A field experiment on collaborative and adversarial caste integration. The American Economic Review 111(6): 1807-44.

Lutz, Byron. 2011. The end of court-ordered desegregation. American Economic Journal: Economic Policy 3(2): 130-168. 
Massey, Douglas S and Nancy A Denton. 1993. American apartheid: Segregation and the making of the underclass. Harvard University Press.

McPherson, Miller, Lynn Smith-Lovin, and James M Cook. 2001. Birds of a feather: Homophily in social networks. Annual Review of Sociology 27(1): 415444.

Mele, Angelo. 2017. A structural model of dense network formation. Econometrica 85(3): 825-850.

Merlino, Luca Paolo, Max Friedrich Steinhardt, and Liam Wren-Lewis. 2019. More than just friends? School peers and adult interracial relationships. Journal of Labor Economics 37(3): 663-713.

Molloy, Raven S. and Christopher L. Smith. 2019. Internal migration: Recent patterns and outstanding puzzles. Tech. rep., Prepared for Federal Reserve Bank of Boston conference, "A House Divided: Geographic Disparities in Twenty First Century America," Boston, MA, October 4-5.

Monarrez, Tomás E. 2022. School attendance boundaries and the segregation of public schools in the US. American Economic Journal: Applied Economics, forthcoming.

Mousa, Salma. 2020. Building social cohesion between Christians and Muslims through soccer in post-ISIS Iraq. Science 369(6505): 866-870.

Niemesh, Gregory T. and Katharine L. Shester. 2020. Racial residential segregation and black low birth weight, 1970-2010. Regional Science and Urban Economics 83: 103542.

Ning, Jia, Raven Molloy, Christopher L. Smith, and Abigail Wozniak. 2022. The economics of internal migration: Advances and policy questions. Journal of Economic Literature, forthcoming.

Oster, Emily. 2019. Unobservable selection and coefficient stability: Theory and evidence. Journal of Business \& Economic Statistics 37(2): 187-204.

Patacchini, Eleonora and Yves Zenou. 2016. Social networks and parental behavior in the intergenerational transmission of religion. Quantitative Economics 7(3): 969-995.

Polipciuc, Maria, Frank Cörvers, and Raymond Montizaans. 2021. Peers' race in adolescence and voting behavior. IZA Discussion Papers 14140, IZA. 
Reber, Sarah J. 2005. Court-ordered desegregation successes and failures integrating American schools since Brown versus Board of Education. Journal of Human Resources 40(3): 559-590.

Rossell, Christine H. and David J. Armor. 1996. The effectiveness of school desegregation plans, 1968-1991. American Politics Quarterly 24(3): 267-302.

Schelling, Thomas C. 1971. Dynamic models of segregation. Journal of Mathematical Sociology 1(2): 143-186.

Schindler, David and Mark Westcott. 2021. Shocking racial attitudes: Black GIs in Europe. The Review of Economic Studies 88(1): 489-520.

Shertzer, Allison and Randall P Walsh. 2019. Racial sorting and the emergence of segregation in American cities. Review of Economics and Statistics 101(3): 415-427.

Soetevent, Adriaan R and Peter Kooreman. 2007. A discrete-choice model with social interactions: With an application to high school teen behavior. Journal of Applied Econometrics 22(3): 599-624.

Torrats-Espinosa, Gerard. 2021. Using machine learning to estimate the effect of racial segregation on COVID-19 mortality in the United States. Proceedings of the National Academy of Sciences 118(7).

Williams, Robin M. 1947. The reduction of intergroup tensions: A survey of research on problems of ethnic, racial, and religious group relations. Social Science Research Council Bulletin 57(xi): 53.

\section{Appendix A Attrition}

Since a significant fraction of the original sample is not included in our main regressions, it is worth considering whether there is any link between our treatment variable of interest and attrition. In Table A9, we take as dependent variables indicators for whether, for a given White individual in wave 1, we observe information on their residential census tract in subsequent waves. In every wave, the coefficients on our terms of interest are insignificant, suggesting that there is unlikely to be a systematic relationship between the treatment variable and attrition in the sample.

We provide a further couple of additional tests of robustness to attrition concerns in Table A10. After providing the baseline results for reference in columns 
Table A9: Attrition across waves

\begin{tabular}{|c|c|c|c|c|c|c|c|c|}
\hline \multirow[t]{2}{*}{ Dependent variable: } & \multicolumn{2}{|c|}{$\begin{array}{c}\text { Observe wave } 2 \\
\text { census tract } \\
\text { Black share }\end{array}$} & \multicolumn{2}{|c|}{$\begin{array}{c}\text { Observe wave } 3 \\
\text { census tract } \\
\text { Black share }\end{array}$} & \multicolumn{2}{|c|}{$\begin{array}{c}\text { Observe wave } 4 \\
\text { census tract } \\
\text { Black share }\end{array}$} & \multicolumn{2}{|c|}{$\begin{array}{c}\text { Observe wave } 5 \\
\text { census tract } \\
\text { Black share }\end{array}$} \\
\hline & (1) & (2) & (3) & (4) & (5) & (6) & (7) & (8) \\
\hline $\begin{array}{l}\text { Grade Black share, } \\
\text { both genders }\end{array}$ & $\begin{array}{c}0.284 \\
(0.177)\end{array}$ & & $\begin{array}{l}0.110 \\
(0.207)\end{array}$ & & $\begin{array}{l}-0.103 \\
(0.210)\end{array}$ & & $\begin{array}{l}-0.275 \\
(0.258)\end{array}$ & \\
\hline $\begin{array}{l}\text { Grade Black share, } \\
\text { same gender }\end{array}$ & & $\begin{array}{l}0.0720 \\
(0.101)\end{array}$ & & $\begin{array}{l}0.0349 \\
(0.140)\end{array}$ & & $\begin{array}{l}-0.0747 \\
(0.117)\end{array}$ & & $\begin{array}{l}-0.109 \\
(0.162)\end{array}$ \\
\hline $\begin{array}{l}\text { Grade Black share, } \\
\text { opposite gender }\end{array}$ & & $\begin{array}{c}0.174 \\
(0.128)\end{array}$ & & $\begin{array}{c}0.107 \\
(0.127)\end{array}$ & & $\begin{array}{l}-0.0511 \\
(0.155)\end{array}$ & & $\begin{array}{l}-0.222 \\
(0.166)\end{array}$ \\
\hline Observations & 11999 & 11999 & 11999 & 11999 & 11999 & 11999 & 11999 & 11999 \\
\hline Adjusted $\mathrm{R}^{2}$ & 0.279 & 0.279 & 0.0390 & 0.0390 & 0.0309 & 0.0309 & 0.0392 & 0.0392 \\
\hline Dep. var mean & 0.717 & 0.717 & 0.731 & 0.731 & 0.780 & 0.780 & 0.592 & 0.592 \\
\hline
\end{tabular}

Notes: The table reports OLS estimates controlling for grade size, language spoken at home in Wave 1, grade-gender fixed effects, and school-gender fixed effects. The sample is all White individuals in Wave 1 that we can link to data on their grade composition. The dependent variables take the value 1 if an individual we have data on their location in the respective wave. Standard errors (in brackets) are clustered at the school level. * $p<.10$, ** $p<.05$, *** $p<.01$

1 and 2, we then run the same regression in columns 3 and 4 on the subset of respondents that could be contacted and responded to the questionnaire on the first attempt of contacting them. In other words, we exclude those who are categorized as being in the Non-Responder Follow-Up (NRFU) part of the Wave 5 survey. If attrition were a driver of our results, we should expect this selected sample to display a stronger effect of exposure to Blacks in high school on their residential choices. However, the coefficients are smaller, suggesting that, if those who never respond share characteristics with those who don't respond on the first contacting, then if anything attrition may be biasing our results downwards. In columns 5 and 6 we return to the full sample, but weight our regressions using the Wave 1-Wave 5 weights provided by Add Health. The results are broadly similar, suggesting that adjusting for attrition based on observables does not change the results in important ways. 
Table A10: Additional results related to attrition

\begin{tabular}{|c|c|c|c|c|c|c|}
\hline & \multicolumn{4}{|c|}{$\begin{array}{l}\text { Excluding those } \\
\text { requring follow-up }\end{array}$} & \multicolumn{2}{|c|}{ Whole sample } \\
\hline & (1) & (2) & (3) & $(4)$ & (5) & (6) \\
\hline $\begin{array}{l}\text { Grade Black share, } \\
\text { both genders }\end{array}$ & $\begin{array}{l}0.190^{* *} \\
(0.0752)\end{array}$ & & $\begin{array}{l}0.189^{* *} \\
(0.0763)\end{array}$ & & $\begin{array}{l}0.0726 \\
(0.126)\end{array}$ & \\
\hline $\begin{array}{l}\text { Grade Black share, } \\
\text { same gender }\end{array}$ & & $\begin{array}{l}0.194^{* * *} \\
(0.0565)\end{array}$ & & $\begin{array}{l}0.164^{* * *} \\
(0.0530)\end{array}$ & & $\begin{array}{c}0.180^{* *} \\
(0.0898)\end{array}$ \\
\hline $\begin{array}{l}\text { Grade Black share, } \\
\text { opposite gender }\end{array}$ & & $\begin{array}{c}0.0128 \\
(0.0564)\end{array}$ & & $\begin{array}{c}0.0483 \\
(0.0554)\end{array}$ & & $\begin{array}{l}-0.100 \\
(0.102)\end{array}$ \\
\hline Sample weights & & & & & Y & Y \\
\hline Observations & 7090 & 7090 & 6448 & 6448 & 7090 & 7090 \\
\hline Adjusted $\mathrm{R}^{2}$ & 0.187 & 0.188 & 0.185 & 0.186 & 0.245 & 0.247 \\
\hline Dep. var mean & 0.0819 & 0.0819 & 0.0811 & 0.0811 & 0.0855 & 0.0855 \\
\hline
\end{tabular}

Notes: Columns 1 and 2 are identical to the columns 1 and 2 of the baseline Table 4 and are provided for reference - please see notes to that table for further details. In columns 3 and 4, we then exclude from the sample those who are Non-Responder Follow-Ups (NRFU). Columns 5 and 6 are identical to the columns 1 and 2 of the baseline Table 4 except that observations are weighted using the sampling weights provided by Add Health. Standard errors (in brackets) are clustered at the school level. $* p<.10, * * p<.05, * * * p<.01$

\section{Appendix B Additional Summary Statistics}

Table B11 presents summary statistics for the variables (measured in wave 1). Figure B4 then shows the distribution of the wave 5 census tract Black share for individuals in our sample. 
Table B11: Summary statistics of variables in balance table

\begin{tabular}{lccccc}
\hline & Mean & SD & Min & Max & N \\
\hline Age & 16 & 1.7 & 12 & 21 & 7090 \\
Parent is Black & .0022 & .047 & 0 & 1 & 6350 \\
Share of census tract Black & .055 & .11 & 0 & .95 & 7034 \\
Share of census block Black & .047 & .11 & 0 & 1 & 7030 \\
Grade size & 224 & 157 & 2 & 697 & 7090 \\
Share same gender & .51 & .07 & .23 & 1 & 7090 \\
Born in USA & .96 & .2 & 0 & 1 & 7090 \\
Lives with both biological parents & .61 & .49 & 0 & 1 & 6326 \\
Number of older siblings & .77 & 1.1 & 0 & 13 & 7081 \\
Years of parental schooling & 14 & 2.2 & 8 & 17 & 6818 \\
Log of family income & 3.7 & .75 & 0 & 6.9 & 5652 \\
Home language is not English & .061 & .24 & 0 & 1 & 7090 \\
Predicted Wave 5 tract Black share & .082 & .027 & -.035 & .29 & 7090 \\
\hline
\end{tabular}

Notes: The table reports summary statistics of all variables in Table 2 . These variables are measured in wave 1.

Figure B4: Distribution of wave 5 census tract Black shares in sample

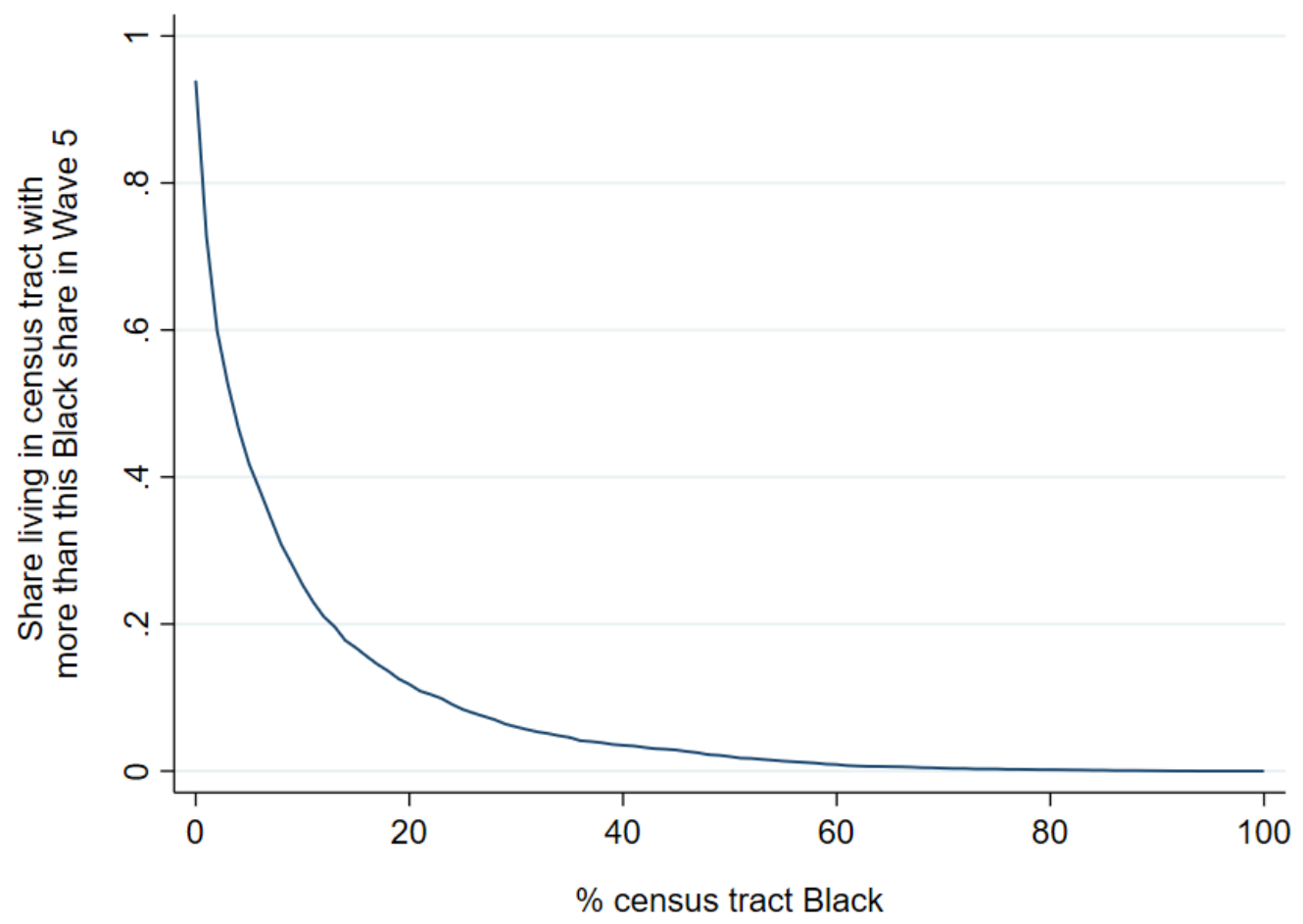




\section{Appendix C Tests for Non-random Clustering}

In this section, we check for non-random clustering of Black students within schools by means of several tests in the sample used to construct these shares. Hence, we use the sample of around 80,000 students who were surveyed in the in-school survey in Wave 1 and who are in cohorts containing at least one student present in our main analysis sample. This is the relevant sample since it is that used to construct our main explanatory variables (i.e., cohort Black shares)—running these tests on our main analysis sample would not be appropriate since there are no Blacks in this sample.

Intuitively, if the share of Black students varies systematically across cohorts, then an individual's race will be significantly correlated with that of their peers. However, a regression of a dummy variable of whether an individual is Black against the Black share of the rest of their peer group would give a negatively biased coefficient. This is because individuals are not included in their own peer group. In the following, we perform several tests designed to avoid this exclusion bias.

Caeyers and Fafchamps (2016) derive a test for non-random clustering that accounts for the exclusion bias by using as a dependent variable a 'transformed Black dummy' $\widehat{B l a c k}_{i}$, where

$$
\widehat{\text { Black }_{i}}=\text { Black }_{i}-\text { bias }_{c s} \times \text { ShareBlack }_{c s},
$$

where Black $_{i}$ is a dummy taking the value 1 if individual $i$ is Black, and bias css $_{c}=$ $\left(N_{s}-1\right)\left(K_{c}-1\right) /\left[\left(N_{s}-1\right)\left(N_{s}-K_{c}\right)+\left(K_{c}-1\right)\right]$, where $N_{s}$ is the number of students in the school and $K_{c}$ the number of students in the cohort.

Column 1 of Table $\mathrm{C} 12$ reports that the regression produces an insignificant coefficient. In Column 2, we perform the same test using the share of Black students split by gender. Again, the coefficients are small and insignificant. Hence, these results are consistent with the assumption of quasi-random allocation of Black students across grades.

Guryan et al. (2009) propose another test of non-random clustering that removes the exclusion bias by controlling for the set of all potential peers. Basically, this means that we have to control for the Black share among all other students in the school in the regression against the Black dummy. Columns 3 and 4 of Table C12 show that the coefficients of interest on the cohort Black shares are again insignificant.

A simple (less formal) test is to regress the male Black share on the female Black share. The coefficient reported in column 5 of Table C12 is insignificant. As most factors which might influence the female Black share would also simultaneously influence the male Black share, we conclude that self-selection or omitted variables when it comes to race shares is unlikely. 
Table C12: Tests for non-random clustering

\begin{tabular}{lccccc}
\hline & $\begin{array}{c}\text { Transformed } \\
\text { black } \\
\text { dummy } \\
(1)\end{array}$ & $\begin{array}{c}\text { Transformed } \\
\text { black } \\
\text { dummy } \\
(2)\end{array}$ & $\begin{array}{c}\text { Black } \\
\text { dummy } \\
(3)\end{array}$ & $\begin{array}{c}\text { Black } \\
\text { dummy } \\
(4)\end{array}$ & $\begin{array}{c}\text { Black share } \\
\text { of males } \\
\text { in grade } \\
(5)\end{array}$ \\
\hline Black share of others in & 0.149 & & 0.00920 & & \\
grade & $(0.210)$ & & $(0.414)$ & & \\
Black share of others of & & 0.00602 & & -0.138 & \\
same gender in grade & & $(0.0989)$ & & $(0.217)$ & \\
Black share of opposite & & 0.0208 & & -0.0337 & \\
gender in grade & $(0.0928)$ & & $(0.233)$ & \\
Black share of others in & & & $-98.69^{* * *}$ & $-101.8^{* * *}$ & \\
school & & & $(23.19)$ & $(22.79)$ & \\
Black share of females & & & & & 0.0616 \\
in grade & & & & & $0.0792)$ \\
\hline Observations & 81780 & 81778 & 81780 & 81778 & 80837 \\
Adjusted $R^{2}$ & 0.999 & 0.394 & 0.395 & 0.398 & 0.979 \\
\hline
\end{tabular}

Notes: The table reports OLS estimates controlling for grade size, language spoken at home in Wave 1, grade-gender fixed effects, and school-gender fixed effects. Regressions reported in this table are run on the Wave 1 in-school survey. Standard errors (in brackets) are clustered at the school level. * $p<.10, * * p<.05, * * * p<.01$

Finally, we check whether differences in Black share across grade are symmetric. The idea is that if Black shares were on average significantly higher (or lower) for later grades, the variation might stem from systematic trends due to factors such a disproportionate dropout rate for Blacks. Hence, we plot in Figure C5 the distribution of the change in Black share between each grade and the previous grade in each school. The figure displays no obvious asymmetry, and indeed the mean change in grade Black share is -0.0005792 .

These tests of random variation therefore accord with the fundamental assumption behind our identification strategy-i.e., that parents don't select into schools on the basis of the grade-specific Black share once we control for the overall school characteristics. A key rational for this assumption is that, in general, parents are unlikely to know before choosing a school how the composition of a particular grade differs from the school average. This rational, however, doesn't prevent selection occurring after children start in a school, and hence one concern may be that White students may differentially change school as a function of the grade Black share. We would be surprised if this behavior was sufficiently widespread to drive our results, but we can look for evidence of it by exploiting Wave 2 of the Add Health survey, which interviewed students who were below grade 12 in Wave 1 (and who 
Figure C5: Kernel density of change in grade Black share

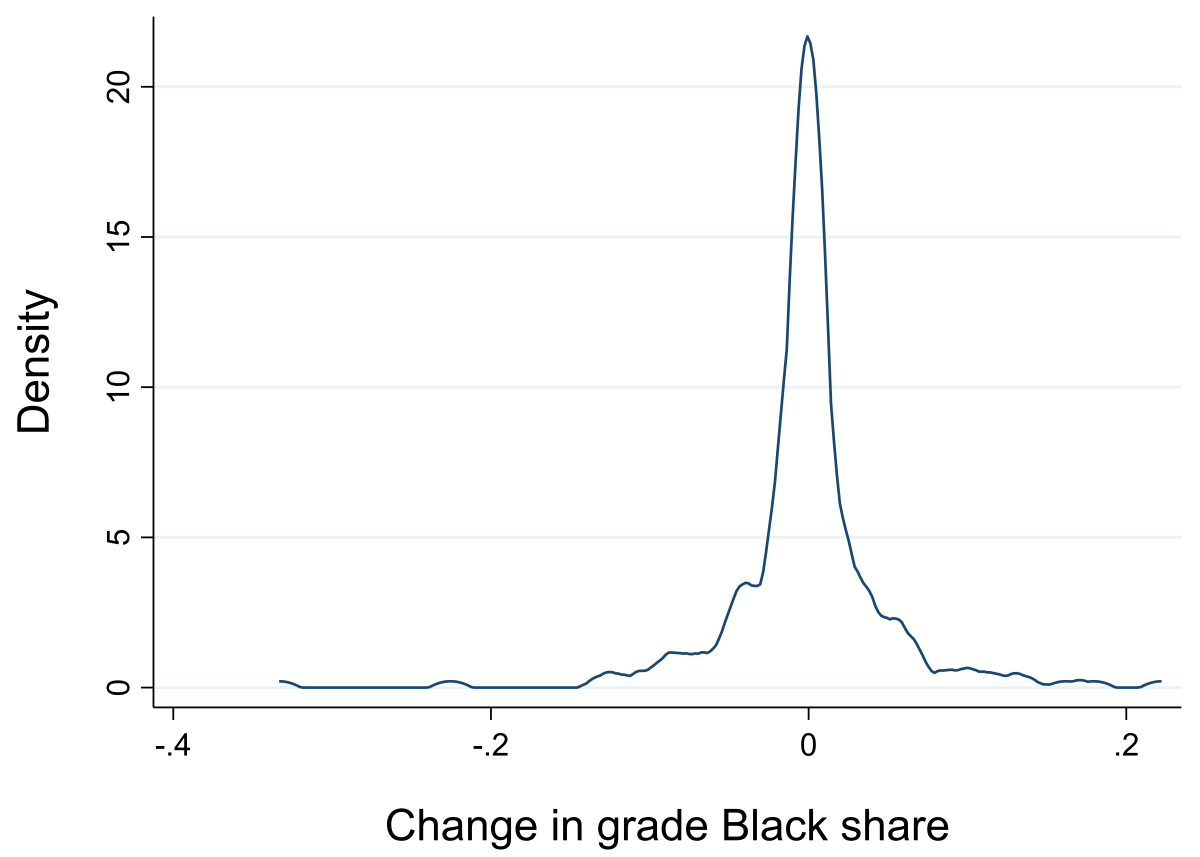

hence would normally have continued in the same school or 'sister school').

Results of this analysis are presented in Table C13. In the first two columns, we see that Whites are not significantly more likely to move school when they have a higher share of Blacks in their grade. This suggests that such school moving behavior is unlikely to be widespread. In columns 3 and 4, we test whether there is any evidence that school switching could be related to our outcome of interest by running a regression similar to our baseline. In particular, we now interact grade Black shares with a dummy for whether the individual switched school. Note that the sample size is substantially smaller since we restrict to those who were below grade 12 in Wave 1 and were surveyed in Wave 2. Since most people didn't switch school, and indeed those that didn't switch are more exposed, it is reassuring that our result is driven by those who didn't switch. If selection was driving our results, we would expect to see that students who move out of grades with high Black shares end up living in less Black neighborhoods, since these are the people who might have selected out of their school based on the Black share. We don't see this to be the case - the coefficients on the relevant interactions are positive-suggesting that even if there is some school switching based on grade Black shares, it is unlikely to be large enough to drive our results. 
Table C13: School switching

\begin{tabular}{|c|c|c|c|c|}
\hline & \multicolumn{2}{|c|}{$\begin{array}{c}\text { Switched } \\
\text { school } \\
\text { in Wave } 2\end{array}$} & \multicolumn{2}{|c|}{$\begin{array}{c}\text { Black share } \\
\text { in census tract, } \\
\text { Wave } 5\end{array}$} \\
\hline & $(1)$ & (2) & (3) & (4) \\
\hline $\begin{array}{l}\text { Grade Black share, } \\
\text { both genders }\end{array}$ & $\begin{array}{l}-0.120 \\
(0.311)\end{array}$ & & & \\
\hline $\begin{array}{l}\text { Grade Black share, } \\
\text { same gender }\end{array}$ & & $\begin{array}{l}0.0348 \\
(0.136)\end{array}$ & & \\
\hline $\begin{array}{l}\text { Grade Black share, } \\
\text { opposite gender }\end{array}$ & & $\begin{array}{l}-0.150 \\
(0.174)\end{array}$ & & \\
\hline $\begin{array}{l}\text { Switched school in } \\
\text { Wave } 2\end{array}$ & & & $\begin{array}{l}-0.00144 \\
(0.00782)\end{array}$ & $\begin{array}{l}-0.00159 \\
(0.00783)\end{array}$ \\
\hline $\begin{array}{l}\text { Grade Black share, } \\
\text { both genders } \times \text { Didn't switch school }\end{array}$ & & & $\begin{array}{l}0.168^{* *} \\
(0.0841)\end{array}$ & \\
\hline $\begin{array}{l}\text { Grade Black share, } \\
\text { both genders } \times \text { Switched school }\end{array}$ & & & $\begin{array}{c}0.0896 \\
(0.0932)\end{array}$ & \\
\hline $\begin{array}{l}\text { Grade Black share, } \\
\text { same gender } \times \text { Didn't switch school }\end{array}$ & & & & $\begin{array}{l}0.164^{* * *} \\
(0.0591)\end{array}$ \\
\hline $\begin{array}{l}\text { Grade Black share, } \\
\text { same gender } \times \text { Switched school }\end{array}$ & & & & $\begin{array}{l}0.0222 \\
(0.192)\end{array}$ \\
\hline $\begin{array}{l}\text { Grade Black share, } \\
\text { opposite gender } \times \text { Didn't switch school }\end{array}$ & & & & $\begin{array}{c}0.0115 \\
(0.0721)\end{array}$ \\
\hline $\begin{array}{l}\text { Grade Black share, } \\
\text { opposite gender } \times \text { Switched school }\end{array}$ & & & & $\begin{array}{l}0.0707 \\
(0.195)\end{array}$ \\
\hline Observations & 8216 & 8216 & 5157 & 5157 \\
\hline Adjusted $\mathrm{R}^{2}$ & 0.561 & 0.561 & 0.205 & 0.205 \\
\hline Dep. var mean & 0.0899 & 0.0899 & 0.0814 & 0.0814 \\
\hline
\end{tabular}

Notes: The table reports OLS estimates controlling for grade size, language spoken at home in Wave 1, grade-gender fixed effects, and school-gender fixed effects. Standard errors (in brackets) are clustered at the school level. The sample in both columns is restricted to Whites who were below grade 12 in Wave 1 and were interviewed in Wave 2 . $*<.10, * * p<.05$, $* * * p<.01$

\section{Appendix D Additional robustness checks}

One concern in studies looking at peer impacts is that measurement error in the independent variable of interest may bias the results upwards (Angrist, 2014). We don't believe this is likely to be a serious issue in our setting given that race is typically measured with much less error than variables such as academic ability. Nonetheless, since race is not an objectively defined variable, there is some potential 
Table D14: Additional Robustness Checks

\begin{tabular}{|c|c|c|c|c|c|}
\hline & (1) & (2) & (3) & (4) & (5) \\
\hline $\begin{array}{l}\text { Grade Black share, } \\
\text { same gender }\end{array}$ & $\begin{array}{l}0.196^{* * *} \\
(0.0566)\end{array}$ & $\begin{array}{l}0.187^{* * *} \\
(0.0533)\end{array}$ & & $\begin{array}{l}0.194^{* * *} \\
(0.0558)\end{array}$ & $\begin{array}{l}0.154^{* * *} \\
(0.0561)\end{array}$ \\
\hline $\begin{array}{l}\text { Grade Black share, } \\
\text { opposite gender }\end{array}$ & $\begin{array}{c}0.0111 \\
(0.0557)\end{array}$ & $\begin{array}{c}0.0106 \\
(0.0511)\end{array}$ & & $\begin{array}{l}0.00206 \\
(0.0588)\end{array}$ & $\begin{array}{c}0.0105 \\
(0.0602)\end{array}$ \\
\hline $\begin{array}{l}\text { Block Black share, } \\
\text { wave } 1\end{array}$ & & $\begin{array}{l}0.138^{* * *} \\
(0.0238)\end{array}$ & $\begin{array}{l}0.138^{* * *} \\
(0.0237)\end{array}$ & & \\
\hline $\begin{array}{l}\text { Blacks in grade, } \\
\text { same gender }\end{array}$ & & & $\begin{array}{l}0.000785^{*} \\
(0.000453)\end{array}$ & & \\
\hline $\begin{array}{l}\text { Blacks in grade, } \\
\text { opposite gender }\end{array}$ & & & $\begin{array}{l}-0.000755 \\
(0.000564)\end{array}$ & & \\
\hline Observations & 7090 & 7090 & 7090 & 7076 & 5966 \\
\hline Adjusted $R^{2}$ & 0.188 & 0.201 & 0.200 & 0.187 & 0.185 \\
\hline Dep. var mean & 0.0819 & 0.0819 & 0.0819 & 0.0817 & 0.0822 \\
\hline
\end{tabular}

for what could be thought of as mismeasurement, we investigate this concern in this section.

One way to check for measurement error is to add variables that may be correlated with the measurement error and observe whether our result changes. We therefore add to our benchmark regression two variables that are likely to be correlated with an individual's 'true' race: a dummy for whether the surveyed individuals identify themselves as Black, and the share of the population that are Black in the census block where they live in Wave 1. The results are shown in column 2 of Table D14, and we include our benchmark regression in column 1 for comparison. Both added variables are positive and highly significant, but the coefficient on the same gender cohort Black share changes little from the benchmark result in column 1 . Another suggestion that has been made to overcome measurement error concerns is to split the sample between the individuals who may be producing the peer effects from those who are being influenced by them Angrist (2014). We do this in column 3 by including the number of Blacks, instead of the share. Even though the variable is likely to be less relevant, we still find a significant effect on our outcome of interest. Overall, these results therefore further suggest that measurement error is unlikely to be driving our results.

In columns 4 and 5 of Table D14 we test the robustness of our result to removing 
two types of individual. In column 4, we remove those who have one parent who reports as black, while in column 5 we remove individuals who are in grade 12 in wave 1 . This latter regression tests whether our results may be driven by differential dropout of Blacks which is likely to occur in grade 12 . In both columns results are similar to our baseline regression.

\section{Appendix E Placebo Tests}

To address concerns that our results may be driven by other cohort characteristics, we perform two different sets of placebo tests. First, we regress the econometric model (1) using as independent variables several same gender cohort shares based on all the appropriate questions included in the in-school survey of Wave 1, i.e., the survey we used to construct the share of Black students in each cohort of the same gender. We constructed over two hundred such variables including, for instance, the share of the cohort who are Hispanic, the share who live with both of their parents, and the share whose most recent history grade was an A. We then record the t-statistics from each regression, and report their distribution in Figure E6. The t-statistics we obtain in our benchmark, indicated by a red line, clearly lies at the very right tail of the distribution. We conclude that it is very unlikely that our result is driven by chance or correlation with another characteristic of school cohorts.

The other placebo test reassigns students to cohorts randomly so that our measure of same gender cohort Black share is that of another random cohort within the same school. We then perform regressions as (1) for each assignment of cohort shares and repeat this exercise ten thousand times. This produces a distribution of coefficients, which is reported in Figure E7 together with the coefficient from our benchmark. The distributions are centered around zero, and the coefficient from our benchmark lies at the very right tail of the distribution. In fact, this is larger than more than 99 percent of the placebo coefficients. This further confirms that our result is not spurious.

The previous placebo test implicitly assumes that cohorts from different grades should have no impact on an individual's residential location. Such an extreme assumption may seem unreasonable given that students are likely to come into some contact with Blacks from other grades. Indeed, we may be curious as to whether we see any impact of adjacent grades' composition on residential segregation. We test for this effect in Table E15 by including the Black share among adjacent grades as additional regressors. Since we don't observe adjacent grade composition for a significant share of our sample, we also include a dummy variable indicating whether each share is observed, and replace missing values with zeros. We can see from columns 1 and 2 of this table that we find no evidence of similar impacts of 
Figure E6: Other shares on RHS.

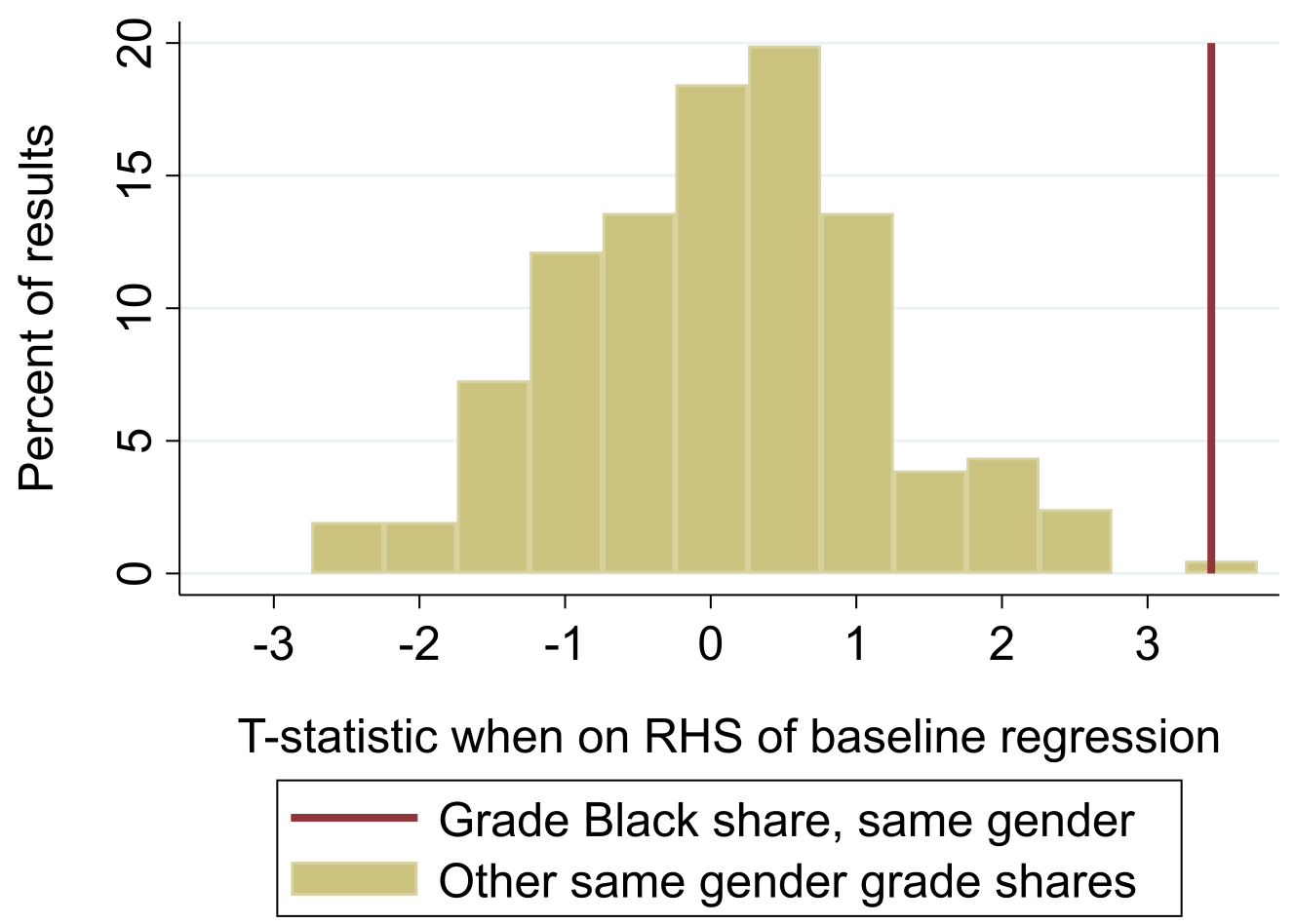


Figure E7: Distribution of coefficients from regressions on randomly assigned cohort shares.

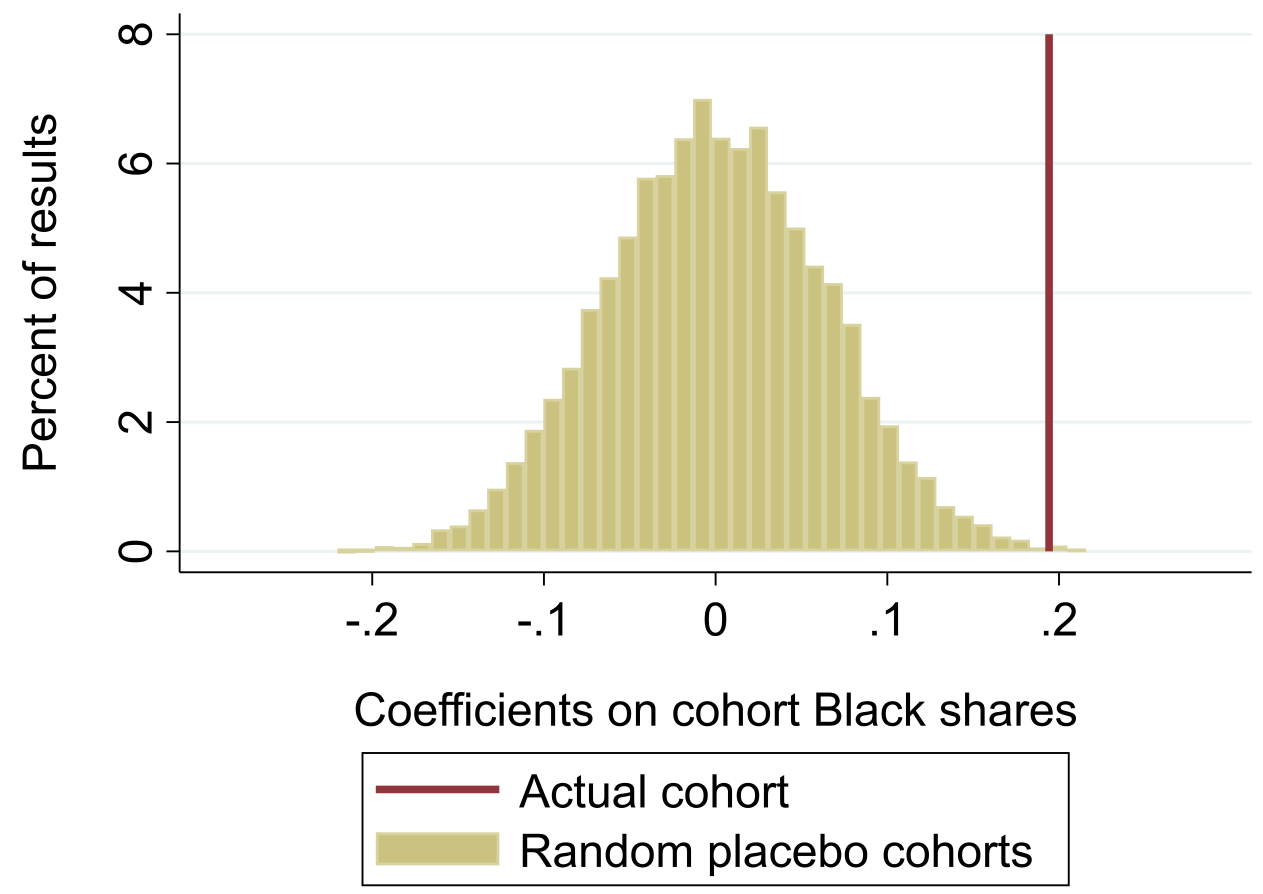

the composition of other grade shares. Note, however, that this doesn't mean that there aren't necessarily impacts of contact with Blacks in other grades, but rather that these don't appear significantly different from contact with Blacks within the school more generally. Indeed, since we are using school fixed effects, in a school with only three grades everybody would be in either the same cohort or an adjacent one. Consistent with this, we show in columns 3 and 4 that there is no impact of adjacent grades Black share on whether an individual has a Black friend. 
Table E15: Impacts of adjacent cohorts

\begin{tabular}{|c|c|c|c|c|}
\hline & \multicolumn{2}{|c|}{$\begin{array}{c}\text { Black share } \\
\text { in census tract, } \\
\text { Wave } 5\end{array}$} & \multicolumn{2}{|c|}{$\begin{array}{c}\text { Has Black friend, } \\
\text { Wave } 1\end{array}$} \\
\hline & (1) & (2) & (3) & (4) \\
\hline $\begin{array}{l}\text { Grade Black share, } \\
\text { both genders }\end{array}$ & $\begin{array}{l}0.179^{* *} \\
(0.0722)\end{array}$ & & $\begin{array}{c}0.177^{*} \\
(0.0964)\end{array}$ & \\
\hline $\begin{array}{l}\text { Grade black share, } \\
\text { both genders, grade above }\end{array}$ & $\begin{array}{l}-0.0517 \\
(0.0389)\end{array}$ & & $\begin{array}{l}-0.0417 \\
(0.0584)\end{array}$ & \\
\hline $\begin{array}{l}\text { Grade black share, } \\
\text { both genders, grade below }\end{array}$ & $\begin{array}{l}-0.0162 \\
(0.0252)\end{array}$ & & $\begin{array}{l}-0.0400 \\
(0.0426)\end{array}$ & \\
\hline $\begin{array}{l}\text { Grade Black share, } \\
\text { same gender }\end{array}$ & & $\begin{array}{l}0.185^{* * *} \\
(0.0550)\end{array}$ & & $\begin{array}{l}0.212^{* * *} \\
(0.0792)\end{array}$ \\
\hline $\begin{array}{l}\text { Grade black share, } \\
\text { same gender, grade above }\end{array}$ & & $\begin{array}{l}-0.0192 \\
(0.0523)\end{array}$ & & $\begin{array}{l}-0.0460 \\
(0.0334)\end{array}$ \\
\hline $\begin{array}{l}\text { Grade black share, } \\
\text { same gender, grade below }\end{array}$ & & $\begin{array}{l}-0.0725 \\
(0.0643)\end{array}$ & & $\begin{array}{c}0.0110 \\
(0.0609)\end{array}$ \\
\hline $\begin{array}{l}\text { Grade Black share, } \\
\text { opposite gender }\end{array}$ & & $\begin{array}{c}0.0165 \\
(0.0540)\end{array}$ & & $\begin{array}{l}-0.00200 \\
(0.0800)\end{array}$ \\
\hline $\begin{array}{l}\text { Grade black share, } \\
\text { opposite gender, grade above }\end{array}$ & & $\begin{array}{l}-0.0304 \\
(0.0554)\end{array}$ & & $\begin{array}{l}0.00557 \\
(0.0533)\end{array}$ \\
\hline $\begin{array}{l}\text { Grade black share, } \\
\text { opposite gender, grade below }\end{array}$ & & $\begin{array}{c}0.0579 \\
(0.0656)\end{array}$ & & $\begin{array}{l}-0.0540 \\
(0.0544)\end{array}$ \\
\hline Observations & 7095 & 7090 & 7095 & 7090 \\
\hline Adjusted $\mathrm{R}^{2}$ & 0.188 & 0.189 & 0.0195 & 0.0207 \\
\hline Dep. var mean & 0.0819 & 0.0819 & 0.0147 & 0.0147 \\
\hline
\end{tabular}

Notes: The table reports OLS estimates controlling for grade size, language spoken at home in Wave 1, grade-gender fixed effects, and school-gender fixed effects. Standard errors (in brackets) are clustered at the school level. $* p<.10, * * p<.05$, $* * * p<.01$

\section{Appendix F Heterogeneity}

In this section, we present an investigation of the presence of heterogeneous effects in our sample with respect to our main results presented in column (2) of Table 4.

We first run the same regression for different subsamples. The results and the $\mathrm{p}-$ values of the tests comparing the coefficients on the different samples are reported in Table F16. Columns (1) and (2) divide the sample by gender, while columns (3) to (6) divide it by region. While we find no significant differences by gender, we do find that the North-East region has a significantly smaller coefficient than the other regions. One potential explanation for this is that, within our sample, school counties in this region appear less segregated than other regions. ${ }^{14}$ To expand on

\footnotetext{
${ }^{14}$ We do not have a direct measure of county segregation, but instead estimate it using the tract Black shares in which Add Health respondents (Black or White) live in Wave 5. In particular, we calculate the dissimilarity index amongst the tracts that we observe, using Blacks and non-Blacks as
} 
this idea, in columns (7) and (8) we split the sample according to whether the school county has a dissimilarity level above or below .5. Consistent with our intuition, our result appears significantly larger in the set of schools in more segregated counties. Note, however, that given we are measuring county-level segregation with error and our sample is not representative at the regional level, this difference between regions should be interpreted cautiously.

Table F16: Subsample splits

\begin{tabular}{|c|c|c|c|c|c|c|c|c|}
\hline & \multicolumn{2}{|c|}{ Gender } & \multicolumn{4}{|c|}{ Region } & \multicolumn{2}{|c|}{ County segregation } \\
\hline & Female & Male & $\begin{array}{l}\text { North- } \\
\text { east }\end{array}$ & $\begin{array}{l}\text { Mid- } \\
\text { west }\end{array}$ & South & West & Low & High \\
\hline \multicolumn{9}{|c|}{ Dependent variable: Any partners Black } \\
\hline & (1) & $(2)$ & (3) & (4) & (5) & (6) & (7) & (8) \\
\hline $\begin{array}{l}\text { Grade Black share, } \\
\text { same gender }\end{array}$ & $\begin{array}{l}0.226^{* * *} \\
(0.0668)\end{array}$ & $\begin{array}{c}0.168 \\
(0.114)\end{array}$ & $\begin{array}{l}-0.0280 \\
(0.0829)\end{array}$ & $\begin{array}{c}0.220 \\
(0.221)\end{array}$ & $\begin{array}{l}0.250^{* * *} \\
(0.0664)\end{array}$ & $\begin{array}{l}0.366^{* *} \\
(0.172)\end{array}$ & $\begin{array}{c}0.101 \\
(0.0761)\end{array}$ & $\begin{array}{l}0.332^{* * *} \\
(0.0786)\end{array}$ \\
\hline $\begin{array}{l}\text { Grade Black share, } \\
\text { opposite gender }\end{array}$ & $\begin{array}{c}0.117^{*} \\
(0.0687)\end{array}$ & $\begin{array}{c}-0.145 \\
(0.0940)\end{array}$ & $\begin{array}{l}-0.0319 \\
(0.119)\end{array}$ & $\begin{array}{l}-0.144 \\
(0.154)\end{array}$ & $\begin{array}{c}0.102 \\
(0.0667)\end{array}$ & $\begin{array}{l}0.0894 \\
(0.181)\end{array}$ & $\begin{array}{l}-0.0196 \\
(0.0477)\end{array}$ & $\begin{array}{l}0.0541 \\
(0.118)\end{array}$ \\
\hline P-val, coefs equal & \multicolumn{2}{|c|}{.66} & \multicolumn{4}{|c|}{.04} & \multicolumn{2}{|c|}{.03} \\
\hline Observations & 3942 & 3148 & 1298 & 2179 & 2413 & 1192 & 4938 & 2149 \\
\hline Adjusted $\mathrm{R}^{2}$ & 0.199 & 0.178 & 0.0550 & 0.105 & 0.186 & 0.0851 & 0.244 & 0.0661 \\
\hline Dep. var mean & 0.0820 & 0.0817 & 0.0545 & 0.0602 & 0.122 & 0.0706 & 0.0856 & 0.0736 \\
\hline
\end{tabular}

Notes: The table reports OLS estimates controlling for grade size, language spoken at home in Wave 1, grade-gender fixed effects, and school-gender fixed effects. The p-values reported in the row after the regression coefficients are results of testing whether the 'grade Black share, same gender' coefficients are statistically different across the relevant samples. Standard errors (in brackets) are clustered at the school level. $* p<.10, * * p<.05$, *** $p<.01$

Table F17 then reports the result of interacting the two treatment variables with the school Black share, the level of segregation of the school calculated using the methodology proposed by Echenique and Fryer (2007), the share of Republican votes in 1992 in the Wave 1 neighborhood, the urban share and the total number of students in one's grade. None of the interaction coefficients are significant.

We also may wonder to what extent the effect depends on the characteristics of the Black children which the White children are exposed to. Carrell et al. (2019) find that exposure to high-performing Black students increases White students' propensity to later have a Black roommate, but exposure to low-performing Black students has no such effect. We test for such an effect by splitting our grade Black shares in various ways in Table F18. In columns 1 and 2, we categorize Blacks by how their self-reported grades compare to the class median. While such a specification is close to Carrell et al. (2019), we may however be concerned that self-reported grades are a noisy measure of performance, and indeed many students do not report any grades. In columns 3-6 we therefore split Blacks according to two measures correlated with performance - whether they live with their father, and whether their our two groups. 
Table F17: Interactions

\begin{tabular}{|c|c|c|c|c|c|}
\hline Interaction term: & $\begin{array}{l}\text { School } \\
\text { Black } \\
\text { share }\end{array}$ & $\begin{array}{c}\text { School } \\
\text { Black } \\
\text { segregation }\end{array}$ & $\begin{array}{c}\text { Republican } \\
\text { vote share } \\
\text { in } 1992\end{array}$ & $\begin{array}{l}\text { School } \\
\text { urban } \\
\text { share }\end{array}$ & $\begin{array}{l}\text { Students } \\
\text { in } \\
\text { grade }\end{array}$ \\
\hline \multicolumn{6}{|c|}{ Dependent variable: Tract Black share } \\
\hline $\begin{array}{l}\text { Grade Black share, } \\
\text { same gender }\end{array}$ & $\begin{array}{c}0.271^{* * *} \\
(0.102)\end{array}$ & $\begin{array}{c}0.169 \\
(0.115)\end{array}$ & $\begin{array}{l}0.185^{* * *} \\
(0.0643)\end{array}$ & $\begin{array}{l}0.211^{* * *} \\
(0.0683)\end{array}$ & $\begin{array}{l}0.237^{* * *} \\
(0.0906)\end{array}$ \\
\hline $\begin{array}{l}\text { Grade Black share, } \\
\text { opposite gender }\end{array}$ & $\begin{array}{c}0.113 \\
(0.0983)\end{array}$ & $\begin{array}{l}-0.0385 \\
(0.0941)\end{array}$ & $\begin{array}{c}0.0152 \\
(0.0585)\end{array}$ & $\begin{array}{l}0.00565 \\
(0.0482)\end{array}$ & $\begin{array}{c}0.102 \\
(0.0705)\end{array}$ \\
\hline $\begin{array}{l}\text { Same gender } \mathrm{x} \\
\text { interaction term }\end{array}$ & $\begin{array}{l}-0.403 \\
(0.408)\end{array}$ & $\begin{array}{l}0.0384 \\
(0.191)\end{array}$ & $\begin{array}{c}0.202 \\
(0.823)\end{array}$ & $\begin{array}{l}-0.109 \\
(0.157)\end{array}$ & $\begin{array}{c}0.000875 \\
(0.000572)\end{array}$ \\
\hline $\begin{array}{l}\text { Opp. gender } \mathrm{x} \\
\text { interaction term }\end{array}$ & $\begin{array}{l}-0.552 \\
(0.377)\end{array}$ & $\begin{array}{l}0.0596 \\
(0.160)\end{array}$ & $\begin{array}{l}-0.215 \\
(0.642)\end{array}$ & $\begin{array}{l}0.0763 \\
(0.113)\end{array}$ & $\begin{array}{c}-0.00000158 \\
(0.000529)\end{array}$ \\
\hline Observations & 7090 & 7022 & 7050 & 7082 & 7090 \\
\hline Adjusted $R^{2}$ & 0.160 & 0.160 & 0.166 & 0.159 & 0.198 \\
\hline
\end{tabular}

mother went to college. In all of these regressions, we don't find significant differences between the coefficients on either of the relevant Black shares, though this may of course reflect a lack of power to detect differences. 
Table F18: Heterogeneity by characteristics of Black peers

\begin{tabular}{|c|c|c|c|c|c|c|}
\hline \multirow[t]{2}{*}{ Characteristic X } & \multicolumn{2}{|c|}{$\begin{array}{l}\text { Above-average } \\
\text { grades/marks }\end{array}$} & \multicolumn{2}{|c|}{$\begin{array}{l}\text { Mother went } \\
\text { to college }\end{array}$} & \multicolumn{2}{|c|}{$\begin{array}{l}\text { Lives with } \\
\text { father }\end{array}$} \\
\hline & (1) & (2) & (3) & (4) & (5) & (6) \\
\hline $\begin{array}{l}\text { Grade Black share, } \\
\text { Blacks with } X=1\end{array}$ & $\begin{array}{l}0.265^{* * *} \\
(0.0999)\end{array}$ & & $\begin{array}{l}0.225^{* * *} \\
(0.0660)\end{array}$ & & $\begin{array}{c}0.142 \\
(0.0997)\end{array}$ & \\
\hline $\begin{array}{l}\text { Grade Black share, } \\
\text { Blacks with } X=0\end{array}$ & $\begin{array}{c}0.160 \\
(0.0996)\end{array}$ & & $\begin{array}{c}0.110 \\
(0.164)\end{array}$ & & $\begin{array}{l}0.239^{* *} \\
(0.118)\end{array}$ & \\
\hline $\begin{array}{l}\text { Grade Black share, } \\
\text { Blacks with } X=1 \text {, same gender }\end{array}$ & & $\begin{array}{l}0.246^{* * *} \\
(0.0753)\end{array}$ & & $\begin{array}{l}0.207^{* * *} \\
(0.0593)\end{array}$ & & $\begin{array}{c}0.171^{* *} \\
(0.0711)\end{array}$ \\
\hline $\begin{array}{l}\text { Grade Black share, } \\
\text { Blacks with } X=0 \text {, same gender }\end{array}$ & & $\begin{array}{c}0.148 \\
(0.0981)\end{array}$ & & $\begin{array}{c}0.159 \\
(0.148)\end{array}$ & & $\begin{array}{l}0.246^{* *} \\
(0.104)\end{array}$ \\
\hline $\begin{array}{l}\text { Grade Black share, } \\
\text { Blacks with } X=1 \text {, opp gender }\end{array}$ & & $\begin{array}{c}0.0481 \\
(0.0693)\end{array}$ & & $\begin{array}{c}0.0262 \\
(0.0675)\end{array}$ & & $\begin{array}{l}0.00747 \\
(0.0628)\end{array}$ \\
\hline $\begin{array}{l}\text { Grade Black share, } \\
\text { Blacks with } X=0 \text {, opp gender }\end{array}$ & & $\begin{array}{l}0.0272 \\
(0.123)\end{array}$ & & $\begin{array}{c}-0.00417 \\
(0.121)\end{array}$ & & $\begin{array}{r}-0.00392 \\
(0.0794)\end{array}$ \\
\hline P-val, coefs equal & .44 & & .51 & & .54 & \\
\hline P-val, coefs equal (same) & & .44 & & .77 & & .51 \\
\hline P-val, coefs equal (opp) & & .89 & & .84 & & .9 \\
\hline Observations & 6971 & 6971 & 7090 & 7090 & 7090 & 7090 \\
\hline Adjusted $\mathrm{R}^{2}$ & 0.192 & 0.193 & 0.188 & 0.188 & 0.188 & 0.188 \\
\hline Dep. var mean & 0.0818 & 0.0818 & 0.0819 & 0.0819 & 0.0819 & 0.0819 \\
\hline
\end{tabular}

Notes: The table reports OLS estimates controlling for grade size, language spoken at home in Wave 1, grade-gender fixed effects, and school-gender fixed effects. Standard errors (in brackets) are clustered at the school level. $* p<.10, * * p<.05$, $* * * p<.01$

\section{Appendix G Additional Results Related to Liberal- ness and Neighbourhood Satisfaction in- dices}

In Table 8 in Section 4, we explored the relationship between school exposure, tract Black share, an index of stated liberalness, and an index of self-reported neighborhood satisfaction. The index of stated liberalness is constructed from three components, and we regress each of these components on our variables of interest in Table G19.

In Table G20, we correlate the index of stated liberalness constructed from these three components with White respondents' tract Black share in each wave, controlling for school-gender fixed effects, grade-gender fixed effects, and the control variables in our baseline regression. Here we can note that there is no significant correlation in the first three waves, but that there is a significant positive correlation in Wave 4 and even more so in Wave 5. We should clearly not take these correlations as causal, but the results are consistent with the idea that attitudes play a larger role in the decision over which neighborhood to live in during later waves. 
Table G19: Impact on (non-standardized) components of stated liberalness index

\begin{tabular}{|c|c|c|c|}
\hline & $\begin{array}{l}\text { Race is not } \\
\text { important in } \\
\text { relationships, } \\
\text { Wave } 3 \\
\text { (1) }\end{array}$ & $\begin{array}{c}\text { Declared } \\
\text { liberalness, } \\
\text { Wave } 4 \\
\text { (2) }\end{array}$ & $\begin{array}{c}\text { Declared } \\
\text { liberalness } \\
\text { Wave } 5 \\
\text { (3) }\end{array}$ \\
\hline $\begin{array}{l}\text { Grade Black share, } \\
\text { same gender }(S)\end{array}$ & $\begin{array}{c}0.199 \\
(0.217)\end{array}$ & $\begin{array}{c}0.317 \\
(0.284)\end{array}$ & $\begin{array}{c}0.378 \\
(0.327)\end{array}$ \\
\hline $\begin{array}{l}\text { Grade Black share, } \\
\text { opposite gender }(\mathrm{O})\end{array}$ & $\begin{array}{l}0.0542 \\
(0.203)\end{array}$ & $\begin{array}{c}0.271 \\
(0.231)\end{array}$ & $\begin{array}{l}-0.317 \\
(0.241)\end{array}$ \\
\hline Observations & 5904 & 6372 & 7090 \\
\hline Adjusted $\mathrm{R}^{2}$ & 0.0529 & 0.0740 & 0.0780 \\
\hline Dep. var mean & 0.623 & -0.989 & -2.074 \\
\hline
\end{tabular}

Notes: The table reports OLS estimates controlling for grade size, language spoken at home in Wave 1, grade-gender fixed effects, and school-gender fixed effects. The variable in column 1 takes a value of 1 if race is declared as being less important than any other aspect of a relationship, and 0 otherwise. The variables in columns 2 and 3 measure liberalness on a 3-point scale, taking the value 1 if the respondent declares to be liberal, -1 if they declare to be conservative, and zero otherwise. (Standard errors (in brackets) are clustered at the school level. * $p<.10,{ }^{* *} p<.05$, *** $p<.01$

Note that results are very similar if we control for school cohort Black shares or, for Waves 3-5, if we use measures of stated liberalness collected in the relevant wave (results available upon request).

Table G20: Correlation between Black share and stated liberalness over time

\begin{tabular}{lccccc}
\hline & $\begin{array}{c}\text { Black share } \\
\text { in tract, } \\
\text { Wave 1 } \\
(1)\end{array}$ & $\begin{array}{c}\text { Black share } \\
\text { in tract, } \\
\text { Wave 2 } \\
(2)\end{array}$ & $\begin{array}{c}\text { Black share } \\
\text { in tract, } \\
\text { Wave 3 } \\
(3)\end{array}$ & $\begin{array}{c}\text { Black share } \\
\text { in tract, } \\
\text { Wave 4 } \\
(4)\end{array}$ & $\begin{array}{c}\text { Black share } \\
\text { in tract, } \\
\text { Wave 5 } \\
(5)\end{array}$ \\
\hline Index of stated & 0.000832 & -0.0000453 & 0.00145 & $0.00306^{*}$ & $0.00579^{* * *}$ \\
liberalness & $(0.000993)$ & $(0.00107)$ & $(0.00175)$ & $(0.00180)$ & $(0.00146)$ \\
\hline Observations & 7034 & 5331 & 5843 & 6369 & 7090 \\
Adjusted R $\mathrm{R}^{2}$ & 0.524 & 0.536 & 0.277 & 0.208 & 0.189 \\
Dep. var mean & 0.0546 & 0.0531 & 0.0744 & 0.0831 & 0.0819 \\
\hline
\end{tabular}

Notes: The table reports OLS estimates controlling for grade size, language spoken at home in Wave 1 , grade-gender fixed effects, and school-gender fixed effects. The stated liberalness index is constructed from three variables related to how liberal a person declares themselves to be-see Section 4.3 for details. Standard errors (in brackets) are clustered at the school level. $* p<.10$, ** $p<.05$, $* * * p<.01$

The index of neighborhood satisfaction is constructed using responses to a set of seven questions asked in Wave 2. We use all seven questions to avoid a somewhat 
arbitrary selection. The questions are as follows:

- Do you know most of the people in your neighborhood?

- In the past month, have you stopped on the street to talk with someone who lives in your neighborhood?

- Do people in this neighborhood look out for each other?

- Do you use a physical fitness or recreation center in your neighborhood?

- Do you usually feel safe in your neighborhood?

- On the whole, how happy are you living in your neighborhood?

- If, for any reason, you had to move from here to some other neighborhood, how happy or unhappy would you be?

We standardize answers to each question and code them such that a higher value represents greater satisfaction. We then construct a standardized inverse-covariance weighted index of neighborhood satisfaction using these seven answers (Anderson, 2008). In Table G21 we repeat the regression undertaken in column 6 of Table 8 replacing this index with each of the components. From this, we can note that most of the components are negatively correlated with the relative tract Black share, but this correlation is reduced when individuals are more exposed to Blacks in their cohort. 


\section{Table G21: Regressions with neighborhood satisfaction components}

\begin{tabular}{|c|c|c|c|c|c|c|c|}
\hline & $\begin{array}{l}\text { Know } \\
\text { people } \\
\text { in } \\
\text { n'hood } \\
\text { (1) }\end{array}$ & $\begin{array}{l}\text { Talked } \\
\text { to } \\
\text { people } \\
\text { on } \\
\text { street } \\
(2)\end{array}$ & $\begin{array}{l}\text { People } \\
\text { look out } \\
\text { for each } \\
\text { other } \\
\text { (3) }\end{array}$ & $\begin{array}{l}\text { Use rec } \\
\text { center } \\
\text { in } \\
\text { n'hood } \\
\text { (4) }\end{array}$ & $\begin{array}{c}\text { Feel } \\
\text { safe } \\
\text { in } \\
\text { n'hood } \\
\quad(5)\end{array}$ & $\begin{array}{l}\text { Happy } \\
\text { in } \\
\text { n'hood } \\
(6)\end{array}$ & $\begin{array}{l}\text { Would be } \\
\text { unhappy } \\
\text { if had } \\
\text { to move } \\
\text { (7) }\end{array}$ \\
\hline $\begin{array}{l}\text { Grade Black share, } \\
\text { same gender }(\mathrm{S})\end{array}$ & $\begin{array}{l}-0.197 \\
(0.647)\end{array}$ & $\begin{array}{c}0.146 \\
(0.482)\end{array}$ & $\begin{array}{l}0.0211 \\
(0.382)\end{array}$ & $\begin{array}{l}-0.217 \\
(0.499)\end{array}$ & $\begin{array}{c}0.218 \\
(0.525)\end{array}$ & $\begin{array}{l}0.912^{*} \\
(0.494)\end{array}$ & $\begin{array}{l}-0.0556 \\
(0.725)\end{array}$ \\
\hline $\begin{array}{l}\text { Grade Black share, } \\
\text { opposite gender }(\mathrm{O})\end{array}$ & $\begin{array}{l}-0.280 \\
(0.454)\end{array}$ & $\begin{array}{l}-0.432 \\
(0.464)\end{array}$ & $\begin{array}{l}-0.548 \\
(0.385)\end{array}$ & $\begin{array}{c}0.427 \\
(0.411)\end{array}$ & $\begin{array}{l}-0.355 \\
(0.485)\end{array}$ & $\begin{array}{c}0.672 \\
(0.415)\end{array}$ & $\begin{array}{c}0.797 \\
(0.543)\end{array}$ \\
\hline $\begin{array}{l}\text { Relative tract Black } \\
\text { share, Wave } 2(\mathrm{R})\end{array}$ & $\begin{array}{l}-8.081^{* * *} \\
(0.639)\end{array}$ & $\begin{array}{l}-5.402^{* * *} \\
(0.637)\end{array}$ & $\begin{array}{l}-0.339 \\
(0.746)\end{array}$ & $\begin{array}{c}-3.303^{* * *} \\
(0.695)\end{array}$ & $\begin{array}{c}-4.593^{* * *} \\
(0.621)\end{array}$ & $\begin{array}{c}2.536^{* * *} \\
(0.661)\end{array}$ & $\begin{array}{l}-0.518 \\
(0.724)\end{array}$ \\
\hline $\mathrm{S} \times \mathrm{R}$ & $\begin{array}{c}13.95^{* * *} \\
(4.017)\end{array}$ & $\begin{array}{c}4.189 \\
(3.096)\end{array}$ & $\begin{array}{l}9.358^{* *} \\
(3.788)\end{array}$ & $\begin{array}{l}-1.127 \\
(4.728)\end{array}$ & $\begin{array}{l}8.345^{*} \\
(4.297)\end{array}$ & $\begin{array}{c}6.608 \\
(3.988)\end{array}$ & $\begin{array}{c}9.189 \\
(5.828)\end{array}$ \\
\hline $\mathrm{O} \times \mathrm{R}$ & $\begin{array}{l}-3.011 \\
(5.058)\end{array}$ & $\begin{array}{c}5.648 \\
(4.327)\end{array}$ & $\begin{array}{l}-2.677 \\
(6.925)\end{array}$ & $\begin{array}{c}6.863 \\
(4.655)\end{array}$ & $\begin{array}{c}8.484 \\
(5.963)\end{array}$ & $\begin{array}{c}0.520 \\
(4.555)\end{array}$ & $\begin{array}{c}0.695 \\
(3.768)\end{array}$ \\
\hline $\begin{array}{l}\text { Observations } \\
\text { Adjusted } \mathrm{R}^{2}\end{array}$ & $\begin{array}{l}5327 \\
0.116\end{array}$ & $\begin{array}{c}5327 \\
0.0537\end{array}$ & $\begin{array}{c}5264 \\
0.0400\end{array}$ & $\begin{array}{c}5326 \\
0.0614\end{array}$ & $\begin{array}{c}5324 \\
0.0915\end{array}$ & $\begin{array}{c}5329 \\
0.0438\end{array}$ & $\begin{array}{c}5319 \\
0.0329\end{array}$ \\
\hline
\end{tabular}

Notes: The relative tract Black share $(\mathrm{R})$ is the share of census tract residents that are Black (measured in Wave 2 in column 5 and Wave 3 in column 6) minus the median of this variable among those in our sample who attended the same school. The table reports OLS estimates controlling for grade size, language spoken at home in Wave 1, grade-gender fixed effects, and school-gender fixed effects. The variable $\mathrm{R}$ is interacted with this set of controls-coefficients reported for these variables are therefore the marginal effects at the sample means. Standard errors (in brackets) are clustered at the school level. $* p<$ $.10, * * p<.05, * * * p<.01$ 